INTERDISCIPLINARIA ARCHAEOLOGICA NATURAL SCIENCES IN ARCHAEOLOGY

Thematic Review

\title{
Contextualising Artisanal Interplay and Technological Changes on Iron Age Naxos (Cyclades). Some Preliminary Observations
}

\author{
Xenia Charalambidou ${ }^{1 *}$

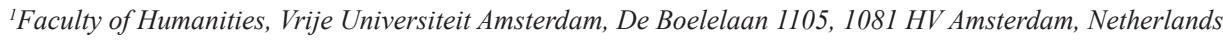

\section{ARTICLE INFO}

\section{Article history:}

Received: $12^{\text {th }}$ March 2021

Accepted: $10^{\text {th }}$ November 2021

DOI: http://dx.doi.org/10.24916/iansa.2021.2.15

Key words:

Iron Age

Mediterranean

the Cyclades

Naxos

potting traditions

artisanal interplay

\begin{abstract}
$A B S T R A C T$
Iron Age Naxos in the Cyclades offers a nuanced insight into potting traditions of fine and coarse wares. Geometric Naxian coarse-ware pots belong to a hand-building tradition that was practised alongside Naxian wheel-made fine wares. Although hand-built, certain Naxian coarse vessels, i.e., storage amphorae and cooking jugs, from the second half of the $8^{\text {th }}$ century BC onwards, show the use of rotational devices in roughouts and shaping to varying degrees, as preserved in the Tsikalario cemetery in inland Naxos. This thematic review, which serves as an introduction to on-going research, sets out the goals and approaches of a technological study which is also investigating the use of rotational devices on Iron Age Naxian vessels alongside other co-existing (hand-made) potting traditions. It is argued that such technological phenomena/changes observed are part of a wider picture that includes interactions and cross-fertilisation between ceramic artisans in the Iron Age settlements of the island.
\end{abstract}

\section{Introduction}

Scholars nowadays, starting with Peregrine Horden and Nicholas Purcell's (2000) seminal book The Corrupting Sea: A Study of Mediterranean History, increasingly argue that in the Mediterranean Basin we witness a long-term interplay between the geographies of microregions and microenvironments, and the broader connectivity between coastal and upland settlements (see Broodbank, 2000; 2013; Norwich, 2006; Abulafia, 2010; Knapp and van Dommelen, 2014; Bonnier, 2016). Current research on Mediterranean islands in particular, in different periods of antiquity, demonstrates that insularity, fragmentation and maritime connectivity were key features of these communities (Broodbank, 2000; Constantakopoulou, 2007; 2017). Islands - due to their physical circumstances - constitute naturally defined microcosms and can be considered "laboratories" for the study of socio-cultural processes in the past. The same

*Corresponding author. E-mail: xenia.charalambidou@gmail.com geographical circumstances dictate that island communities are forced to make strategic choices - to either remain isolated or become connected.

The Early Iron Age (EIA) and especially the $8^{\text {th }}$ century BC was a period of major transformations within Greek societies that beheld an intensification of settlement and population growth, resulting in connectivity and mobility between both neighbouring and far-flung communities, such as were created by the Greek diaspora movements to southern Italy and Sicily. Several Aegean regions, including Euboea and Naxos in the Cyclades, revived their trade networks in the Mediterranean soon after the collapse of the Mycenaean palatial systems, especially from the $10^{\text {th }}$ century BC onwards. On Naxos (Figure 1), the largest Cycladic island, evidence of an increasing connectivity in material culture is also seen between communities of the coast (harbour town of Naxos) and the rural hinterland, intensifying further in the $8^{\text {th }}$ century BC. The ceramic products of Naxian craftsmanship can enhance our understanding of interactions between the local communities of the island and beyond. 


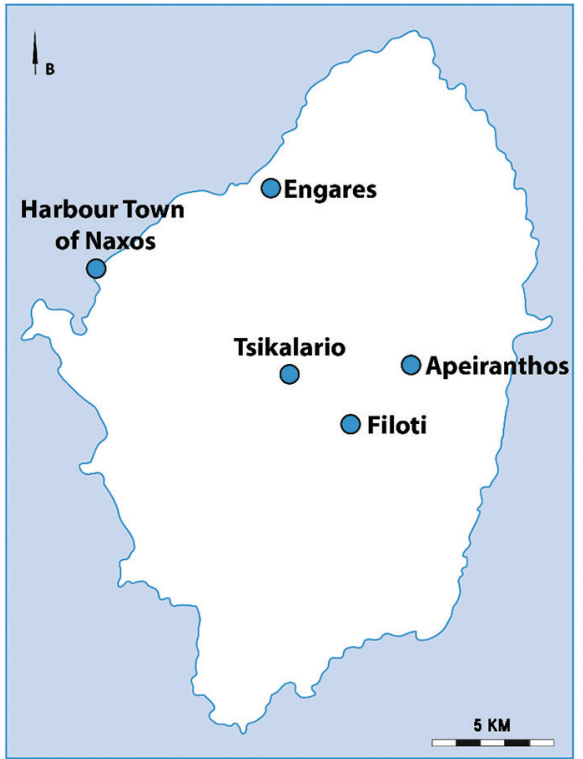

(a)

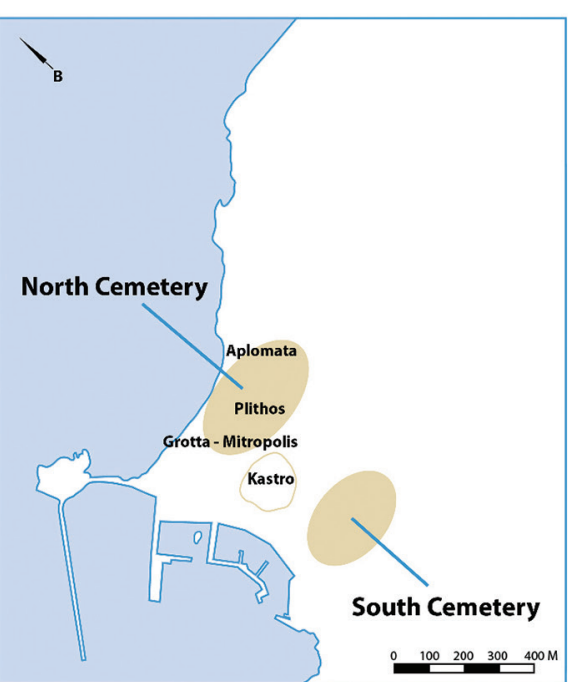

(b)
Figure 1. a) Map of Naxos, with sites mentioned in the text; b) The harbour town of Naxos with main sites (primarily burial areas) that yielded EIA remains.

\section{Approach}

Within the NWO-funded Melting Pot Project at Vrije Universiteit Amsterdam, ${ }^{1}$ which examines interconnections between the Greek motherlands and the "colonial" and indigenous milieux in southern Italy and Sicily, my postdoctoral research (Subproject 3: "Pots \& Pans: analysis and comparison of pottery production and consumption in ancient Greek mother-cities and in indigenous and colonial communities in Italy [ca 800-550 BC]'), initiated in 2020, includes the investigation of ancient potters' interplay and mobility between Greece and southern Italy-Sicily.

To understand artisanal interplays at a regional and interregional level, my efforts currently concentrate on characterising and documenting the different pottery chaînes opératoires or production sequences to postulate the degree and range of social dynamics and interactions of communities in contact (Leroi-Gourhan, 1993; Gosselain, 2000; Albero Santacreu, 2017; description and identification recently in Roux and Courty, 2019).

Specific research questions are constructed within the framework of:

1) The identification and characterisation of different potting traditions at different scales, e.g., urban/ countryside, coastal/hinterland, indigenous/immigrant.

2) Documenting changes in those traditions.

3) Understanding the nature and range of technological changes that will help us appreciate in turn issues of transmission of technical and stylistic knowledge, "communities of practice" (Lave and Wenger, 1991; Wenger, 1998; Roddick and Stahl, 2016), the social

\footnotetext{
1 The full title of the multi-disciplinary Melting Pot Project is: "What went into the melting pot? Land-use, agriculture, and craft production as indicators for the contributions of Greek migrants and local inhabitants to the so-called Greek "colonisation" in Italy" (NWO-funded project no. VC.GW17.136, directed by Prof. J.P. Crielaard), see Crielaard et al., 2020.
}

organisation of production and formation of social groups and identities.

4) How production practices related to consumption choices within different communities.

Characterising and differentiating between Iron Age local potting traditions on Cycladic Naxos (Figure 1a) is part of the research I am conducting in the framework of the Melting Pot Project. Naxos, according to later colonisation mythography, participated in the Greek diaspora movements to Italy, by being, together with Chalcis on Euboea, a partner in the foundation of Sicilian Naxos (734 BC).

This thematic review serves as an introduction to ongoing research that explores Cycladic Naxian craftsmanship, summarising also previous work on Naxian pottery studies.

\section{Methodological considerations and restrictions}

There are several initial constraints operating in terms of finding the proper contexts, i.e., much of this evidence for the EIA and Archaic period is fragmentary and preserved contexts vary from region to region, but even so many aspects of production and consumption during these periods can be remarked, based on the existing evidence within ancient settlement areas.

The Melting Pot Project Subproject 3 research combines macroscopic approaches (morphological, typological, stylistic), including macro-trace documentation of forming and finishing techniques, ${ }^{2}$ a literature study of ethnoarchaeological research,

\footnotetext{
2 The macro-trace documentation (to be photographed by the archaeological photographer Bob Miller) has been developed as a research tool by Beatrice McLoughlin to characterise the coarse-ware traditions practised at the Iron Age settlement of Zagora on Andros. It is based on the methodologies and taxonomies developed by Agnes Gelbert to capture potential archaeological traces of forming and finishing techniques within distinct multi-stage hand
} 
science-based analyses, i.e., petrographic and elemental analyses and SEM (Scanning Electron Microscope), as well as geological investigation of the production sites and experimental reconstructions (re-firing tests of pottery, firing of natural clays). Provenance analyses are used because they can significantly contribute to questions of cultural contacts, spatial and social mobility and the negotiation of identities.

For EIA Naxian pottery, part of the petrographic and elemental (WD-XRF) analyses has been conducted. ${ }^{3}$ Additional samples will supplement this research both from coastal (from the Mitropolis Square-Grotta area at the harbour town) and from hinterland regions (Tsikalario). Further analyses, especially X-radiography, will also be conducted for the documentation of certain ceramic categories, i.e., coarse wares formed or finished with the assistance of a rotational device. ${ }^{4}$

To broaden the scope of this study, collaboration between Gloria London, Beatrice McLoughlin (Iron Age Andros), and the author of this paper (Iron Age Naxos) provides awareness of the various possible ways technological processes could have taken place in the Iron Age Cyclades (based on London's detailed work on the Cypriot traditional female potters in Kornos and Agios Demetrios in the Troodos mountains: London, 2000; 2020). ${ }^{5}$ Our aim here is not to develop interpretative clues based on these ethnographic contexts (cf. Gosselain, 2016) - there are significant chronotypological and regional differences in the context London researched and in the contexts we are examining in the Iron Age Cyclades - but to contribute towards the creation of an "ethnography" of the Iron Age Naxian and Andriot potting traditions. ${ }^{6}$ Among the technological features London documented is that the Troodos female potters utilised the

building traditions of practising potters, and points of transfer between traditions, as part of the Mali Potters Project (Gelbert, 2003; Gallay, et al., 2012).

3105 samples from the cemetery of Tsikalario in inland Naxos and from the Plithos burial ground at the harbour town of Naxos; first results in Charalambidou et al., 2017.

4 We should mention that there are certain limitations which impose the selection of certain types of analyses. Regarding the ceramic material from the necropolis of Tsikalario, for example, most pots are almost complete or largely restored (in previous decades), therefore, the examination of fresh radial sections using a stereomicroscope for the characterisation of technological features formed with the assistance of the wheel cannot be conducted (this analysis requires sampling at around the mid-height of the vessels: Roux, 2019, passim). X-radiography, therefore, a valued tool for the identification of manufacturing methods, seems to be the only possible solution here (see Berg, 2009). Solutions need to be found for the transfer of necessary equipment to Naxos for the conduct of this type of analysis. Similar problems may have forced other scholars to analyse via X-radiography a small number of samples (and usually small-sized pots), with the exception of Ina Berg's (2009) detailed work, who managed to process ninety-five open and closed coarse, semi-coarse and fine Cretan vessels, dating from Early Minoan III through to Late Minoan II.

${ }^{5}$ Documentation of pre-industrial Cyprus by London reveals the performative interplay of the potters' actions, the clay medium, the tools they used to shape it, exchange of motor skills, visits between potting communities (based on kinship ties and teacher-apprenticeship networks), and the movements of practitioners.

${ }^{6}$ Cf. Hamilakis, 2016 who proposes the term "archaeological ethnography". turntable to shape medium-size and larger vessels, offering insights for possible ways of the use of the rotational devices in roughouts and shaping to varying degrees for the Iron Age contexts on Naxos and Andros.

\section{From the Bronze to the Iron Age}

After the introduction of the wheel in the Aegean during the Early and Middle Bronze Age, the potter's wheel was used throughout the Late Bronze era. Increasing evidence from Bronze Age Crete (e.g., Jeffra, 2011; 2013; Berg, 2015) and the Cyclades (Berg, 2007a; 2007b; Gorogianni et al., 2016; Abell and Hilditch, 2016) indicates that pottery production using the wheel was much more variable than originally thought, implying complex technological phenomena that involved different potting communities. Mycenaean pottery was produced on such a device for numerous categories, from painted vessels to unpainted fine to medium-coarse classes in a wide range of regions from the Peloponnese to Thessaly (Choleva et al., 2020, with bibliography). Overall, there is now a growing body of research on Bronze Age regional productions and the complex patterns of the uptake of new techniques and vessel types in various parts of the Aegean (Gauß et al., 2015; Abell and Hilditch, 2016; Kiriatzi and Knappett, 2016; Lis et al., 2020), which is changing our understanding of the nature of ceramic traditions, and both communities of practice and of consumption.

The effect of the collapse of the Mycenaean palatial system on pottery production in the transition from the Bronze to the Iron Age remains a terra incognita area of research in many areas of the Greek world, including the Cyclades. It, nevertheless, is becoming evident that EIA vessels dedicated to the consumption of drink and food, often of fine/semifine fabrics, are usually made on the wheel (although fine hand-made wares can also be found), and when examined in relation to the medium or coarse hand-made wares they seem to indicate distinct modes of production (see Strack, 2007, p.256). Only one technological study to date exists relating to the EIA central Aegean that documents pottery chaînes opératoires (of fine wares) after the disintegration of Mycenaean palaces; thanks to this study by Štěpán Rückl and Loe Jacobs (2016) very recently the picture as we know it for the Protogeometric period has begun to alter, but this, for the time being, concerns only fine wares. Rückl and Jacobs have argued that, contrary to the established notion that wheel-throwing was the exclusive technique used to produce Protogeometric fine-ware pottery, at least part of this ceramic category was actually wheel-coiled, as evidence shows from Mitrou, Halos and Lefkandi in central Greece.

Sara Strack's (2007) and Jean Sébastien Gros' (2007) $\mathrm{PhD}$ theses have also created a solid foundation against which other sections of the ceramic material culture can be characterised and documented technologically in the future (see also Lis, 2009). Strack's research concentrated on Late Bronze Age (LBA) and EIA hand-made pottery, mostly of 


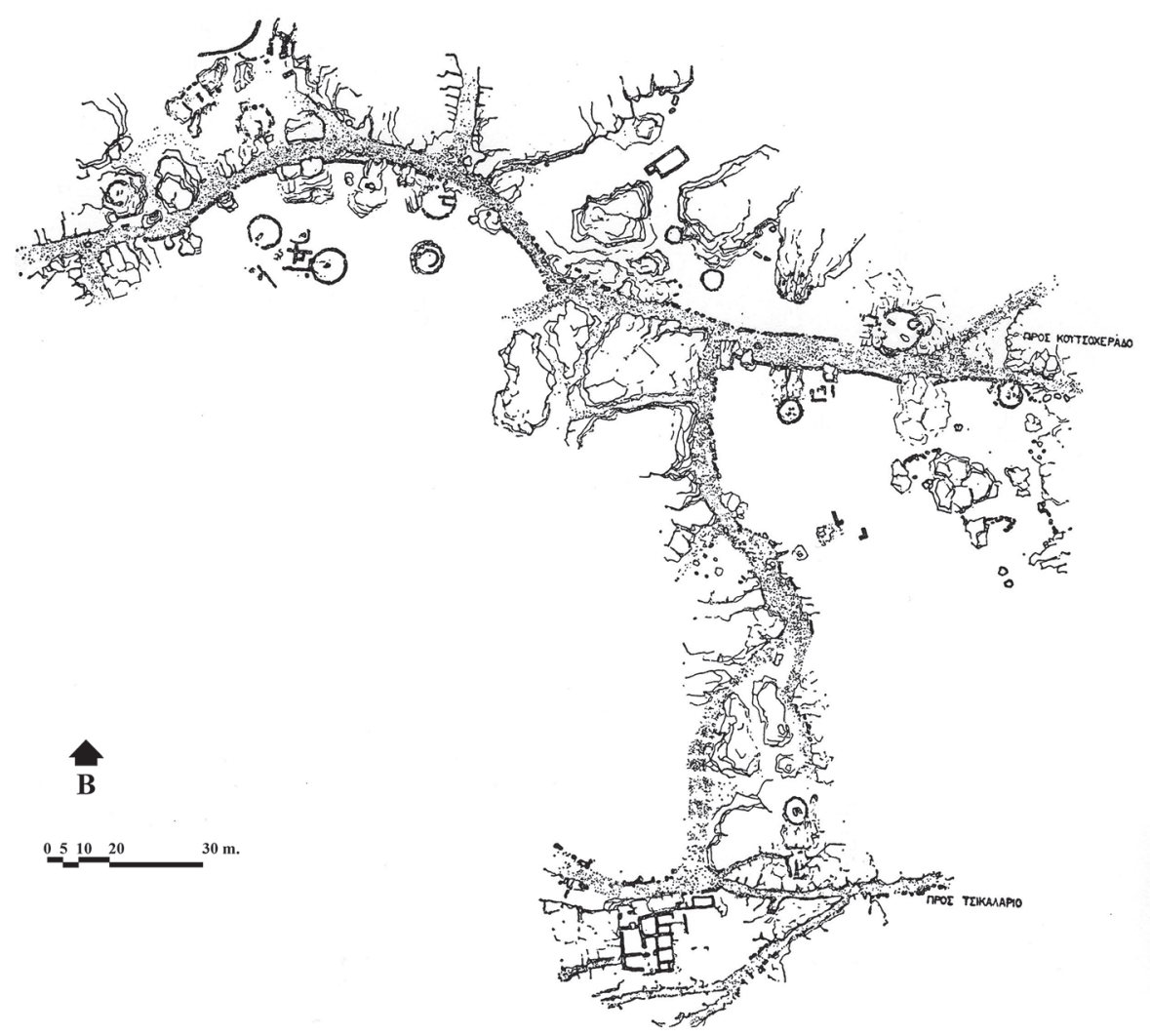

Figure 2. a) Plan of the cemetery of Tsikalario in inland Naxos (after Zaphiropoulou, 1983, p.3, map N.I); b) Low Tumulus 6 - interior and exterior periphery (after Papadopoulou-Zaphiropoulou, 1965, p.517, Figures 14-15).

(a)

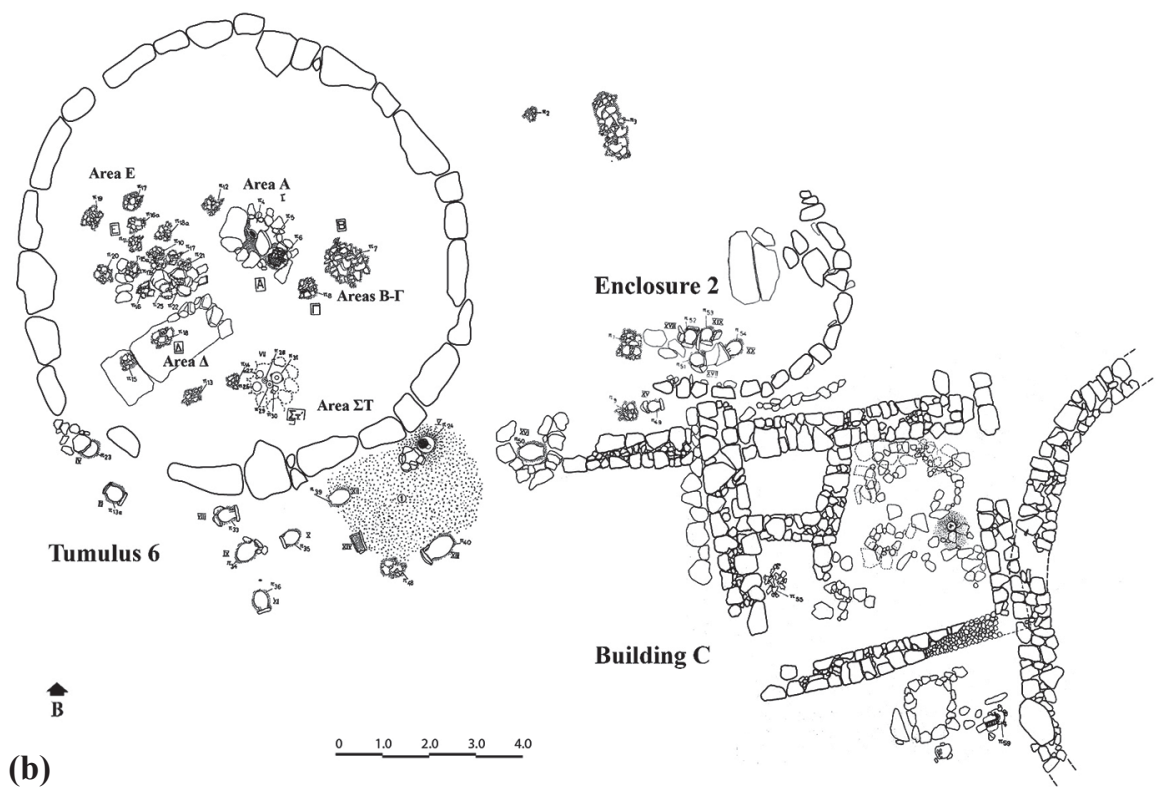

a utilitarian character: this comprises a section of material evidence which appeared in the late Mycenaean period and coincides with major destructions of Mycenaean citadels and continued in production under the new sociocultural developments in the EIA. According to Strack (2007, pp.256-257), "comparison with similar patterns of change in the archaeological record of different periods, as well as with developments documented in ethnographic studies, indicate that the introduction of EIA-type hand-made wares resulted from changes in economic circumstances, disruptions of routes of exchange and communication, and rapidly changing structures of the social fabric; consequently, the occurrence of hand-made wares in LBA and EIA Greece is better described as the development, rather than introduction, of a new ceramic type".

On Cycladic Naxos, multidisciplinary technological research is now being initiated for the first time. Archaeometric (chemical) analyses of Naxian pottery in the 
past (Jones, 1986, pp.265-267, p.280; Grimanis et al., 1989) contributed significantly by identifying chemical properties of Naxian ceramic fabrics, but did not address questions of identification and characterisation of Naxian pottery traditions based on technological features. In our case, the goal is to document contemporaneous potting traditions of both fine and coarse wares.
Several aspects deserve particular attention. For instance, there is evidence for the incorporation of rotational devices in the production of hand-built coarse ware vessels - alongside the use of the wheel for fine wares - found in the cemetery of Tsikalario in inland Naxos. This is first observed in the closed context of low Tumulus 6 (see below) that may date this practice from (at least) the mid- or the third-quarter of

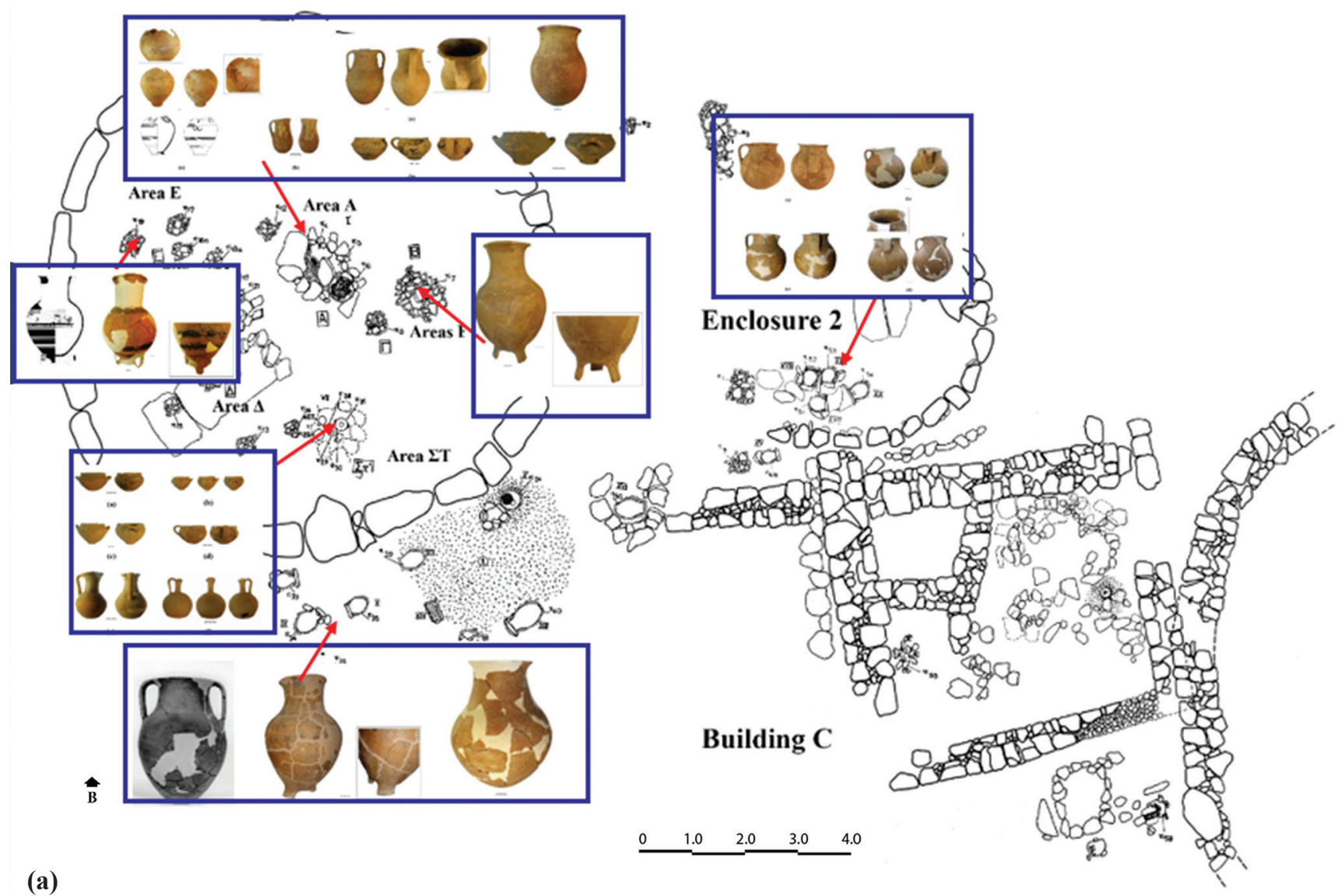

(a)

Minimum number of vessels (MNI) in funerary structure 6 (general use categories)
C (coarse)

FSF (fine/semi-fine)
Figure 3. a) Tsikalario. Representative finds from Areas A, B- $\Gamma, \Delta, \mathrm{E}, \Sigma \mathrm{T}, \Lambda$ inside low Tumulus 6 and from the exterior periphery of the tumulus; b) Minimum number of vessels in the interior of Tumulus 6. Figure by X. Charalambidou.

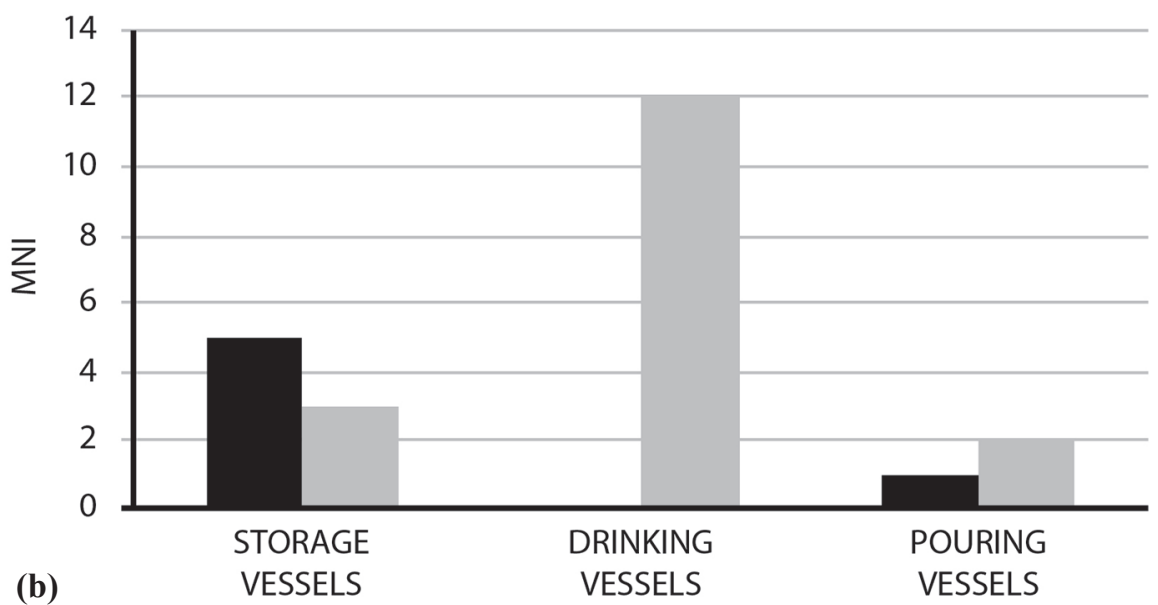



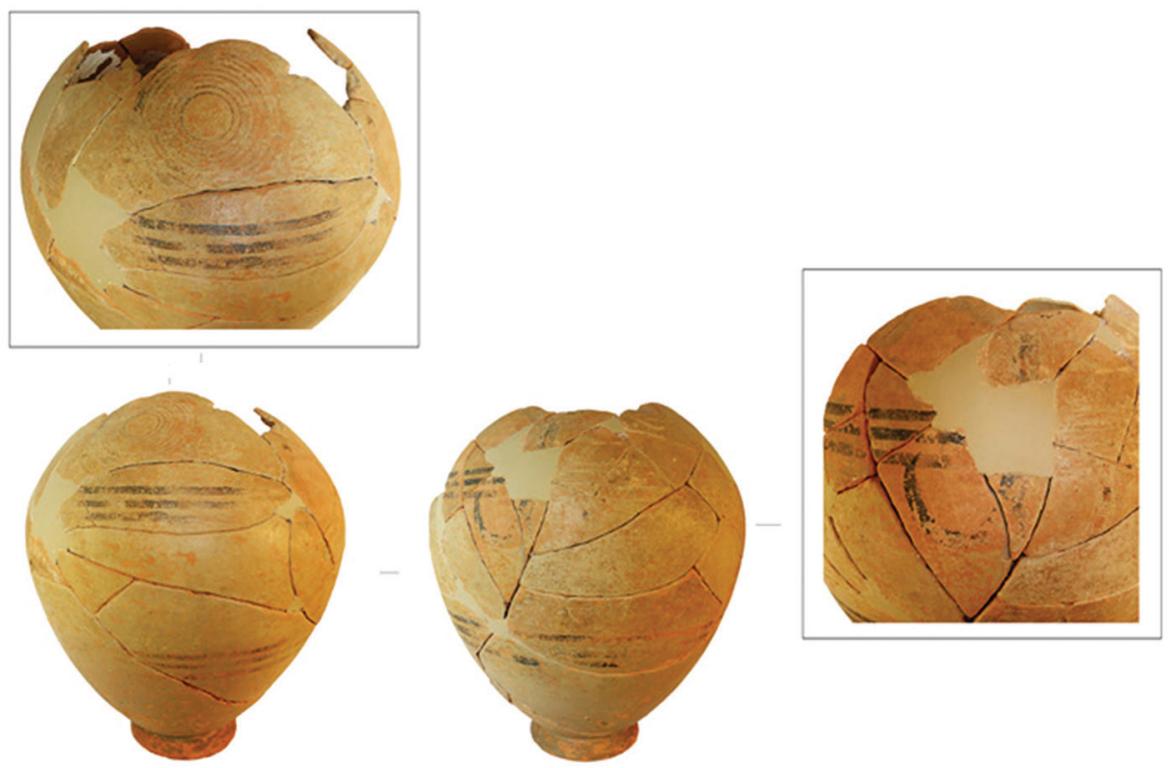

$\infty$
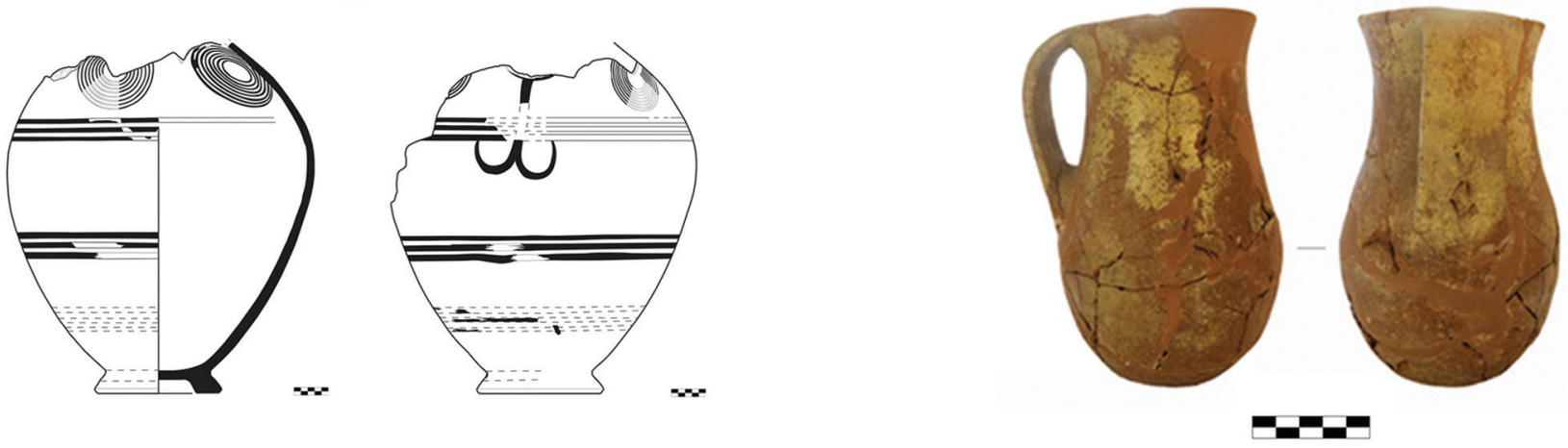

(a)

(b)

Figure 4. Tsikalario. Low Tumulus 6, Area A: a) fine/semi-fine amphora (MN 3828) and b) the small coarse burnished jug (MN 3829) discovered inside. Figure by X. Charalambidou, D. Nenova and B. Konnemann.

the $8^{\text {th }}$ century BC. We cannot exclude the possibility that the use of rotational devices in Naxian EIA coarse wares may have appeared earlier but, to date, such published evidence is missing. Contemporaneous with my research on Naxos, McLoughlin has noticed that the potters of the Iron Age settlement of Zagora on Andros incorporated wheel-shaping into their practice, for a restricted shape range, in the last decades of the $8^{\text {th }}$ century BC (McLoughlin and Paspalas, forthcoming). This is the first time such processes have been documented and our intention (McLoughlin's and mine) is to provide robust comparable datasets for the identification and characterisation of Iron Age Cycladic potting traditions to explore the potential meaning of such microscale changes.

\section{Naxian evidence: first macroscopic and archaeo- metric remarks on the pottery from the cemetery of Tsikalario}

The island of Naxos, with a surface area of $429 \mathrm{~km}^{2}$, is formed from a series of metamorphic Mesozoic rocks, which surround a central dome of migmatite (Evelpidou et al., 2012, p.82 with bibliography; Charalambidou et al., 2017, pp.119-120, with bibliography). It is the largest island in the Cyclades and its geomorphological diversity ranges from coastal areas to inland regions with small valleys. Naxos can offer us a model example for the importance of local connections between a major coastal urban settlement, the harbour town of Naxos (Grotta), and the hinterland.

The ceramic assemblage from the cemetery of Tsikalario, located in Naxos' hinterland in the migmatite heart of the island (Figures 1a and 2a), ${ }^{7}$ is briefly presented here. The assemblage remains the best case-study on EIA-Archaic Naxos for the display of intra-site variation in morphology, primary and secondary roughouts and preform stages ${ }^{8}$ of vessel manufacture for a range of table wares and shapes

\footnotetext{
${ }^{7}$ On the excavations and studies of the material remains from the Tsikalario cemetery: Zaphiropoulou, 1983; 2001a, pp.285-292; 2001b, pp.7-11; 2008-2009; Charalambidou, 2008-2009; 2010-2012; 2011; 2017; 2018; 2021; forthcoming; Charalambidou et al., 2017.

${ }^{8}$ On definitions of the terms: roughout and preform, see Roux, 2019, p.41.
} 


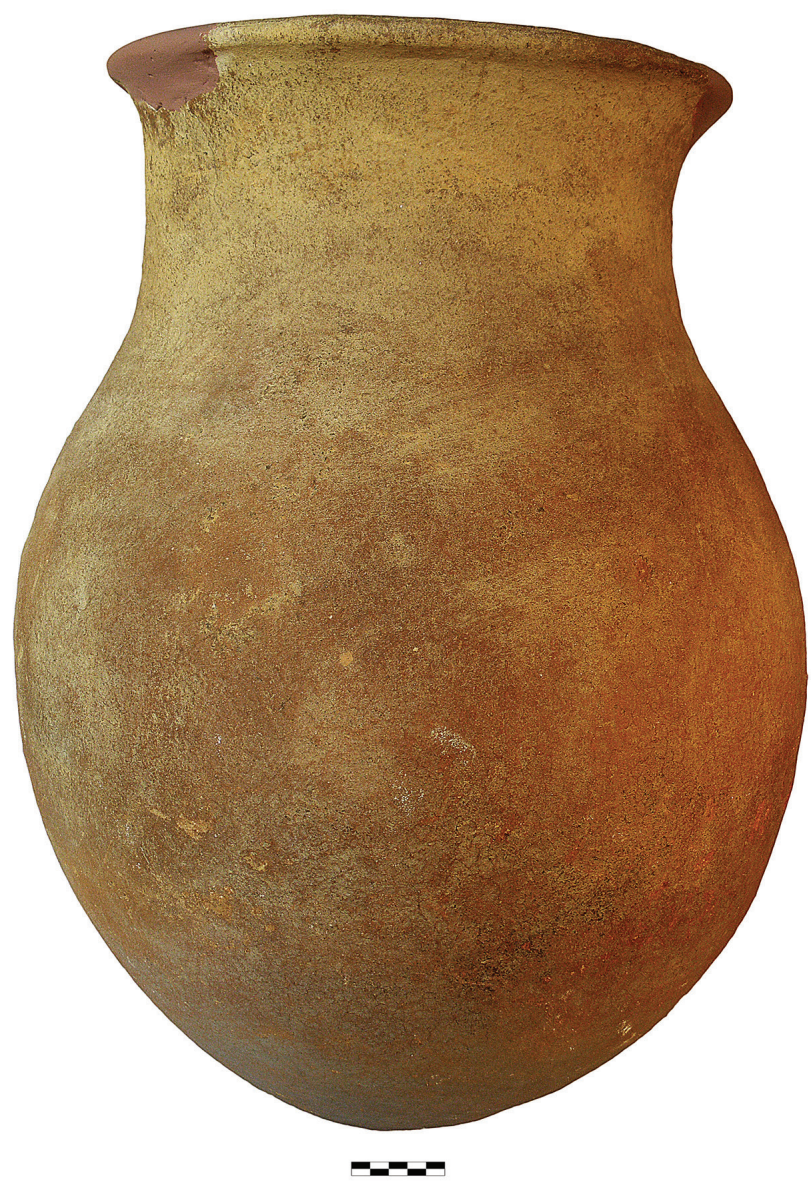

Figure 5. Tsikalario. Low Tumulus 6, Area A: coarse handleless jar with plain base (MN 3827). Photograph by D. Nenova.

for cooking, food processing, transportation and storage: all deposited in the cemetery context and probably in secondary use. ${ }^{9}$

To understand the context, it should be pointed out that in this inland cemetery have been uncovered $8^{\text {th }}$-century $\mathrm{BC}$ circular and ellipsoid funerary structures, i.e., low tumuli. More sporadic burials, structures and offerings were located in the area of the necropolis, at least until the end of the Archaic period (recently Charalambidou, 2018). The low grave-tumuli discovered in the Tsikalario cemetery comprise a mortuary phenomenon not found elsewhere on Naxos during the EIA. It possibly represents an attempt by the kinship group(s) that buried their deceased there to articulate status and identity and differentiate themselves by their mortuary behaviour from people and funerary practices deployed at the harbour town of Naxos.

The state of preservation of the pottery from the Tsikalario funerary structures is varied. Many contexts were robbed; hence the full range of their original contents is not known. There are several, however, which remain intact. One of them is low Tumulus 6 (Figure 2b; Papadopoulou-Zaphiropoulou,

\footnotetext{
9 Their first use would have been in the household judging from the range of utilitarian forms, see Charalambidou, 2021.
}

1965, pp.516-517, drawings 14-15), which is a collective funerary structure. Its interior contains contexts that mainly range in date from the Middle Geometric II to the Late Geometric I period. Several sections within Tumulus 6 have been identified as distinct areas which included burial pots and grave offerings (Areas $\mathrm{A}, \mathrm{B}-\Gamma, \Delta, \mathrm{E}, \Sigma \mathrm{T}, \Lambda$ ) (Figures 2b, 3a).

Within the tumulus, in addition to fine-ware drinking and pouring vessels, a minimum of eight storage (and transport) vessels of fine/semi-fine and coarse ware were uncovered (Figure 3a-b). ${ }^{10}$ The majority of vessels from this context are Naxian. ${ }^{11}$ Fine wares from the interior of the tumulus are "wheel-made" and the coarse wares are "hand-made", ${ }^{12}$ except for one coarse pot (MN 3825) discovered together with other vessels in the most central part of the tumulus. This central, oval-shaped, part of the funerary structure included three storage vessels in an upright position: a fine/semi-fine "archaising" wheel-made transport/storage amphora, Protogeometric in style, in the interior of which a small coarse and burnished hand-made cooking jug was found (Figure 4a-b); a coarse hand-made handleless jar (Figure 5); and the coarse amphora MN 3825, inside which a fine wheel-made kyathos was placed (Figure 6a-b).

This last amphora (MN 3825) (Figure 6a), of Naxian fabric, whose date may range from Middle Geometric II to Late Geometric I (it might even be among the latest vessels deposited inside the tumulus ${ }^{13}$ ), has roughly the shape of a jar, but with two handles which are embellished with horn-like terminals. That this pot was manufactured with the assistance of a rotational device becomes evident from its macro-features: in its interior both the neck and the lower body exhibit horizontal ridges (Figure 6c-d), and the exterior neck-surface preserves horizontal striations consistent with finishing or smoothing a leatherhard vessel with the assistance of rotation (Figure 6a). ${ }^{14}$ Such horizontal interior ridges and exterior striations are not a feature of other Middle Geometric-Late Geometric (I) coarse-ware categories such as the hand-made storage jars (with plain base or tripod foot), which have also been found in Tsikalario (and also in the context of the same tumulus, see e.g., Figures 5 and 7). This last vessel shape also occurs in Agios Ioannis Apeiranthou in inland Naxos

\footnotetext{
${ }^{10}$ On the pottery quantification from this assemblage, see Charalambidou, 2011.

11 Macroscopic fabric descriptions in Charalambidou, 2018.

12 The terms "hand-made" and "wheel-made", as G. London notes, are abbreviations for the many different possibilities of how people make pots. Their chaînes opératoires will also be documented from summer 2022 onwards (see also below).

13 The Middle Geometric II wheel-made fine kyathos discovered in its interior provides a rough date for this amphora.

14 Given the differences in terminology (e.g., Roux, 2019, p.48 and Choleva et. al., 2020, p.222) on rotational devices and the fact that none of them is preserved from EIA-Archaic Naxos, I will avoid hypothetical characterisations, i.e., whether it is a turntable/tournette or another type of rotational device.
} 

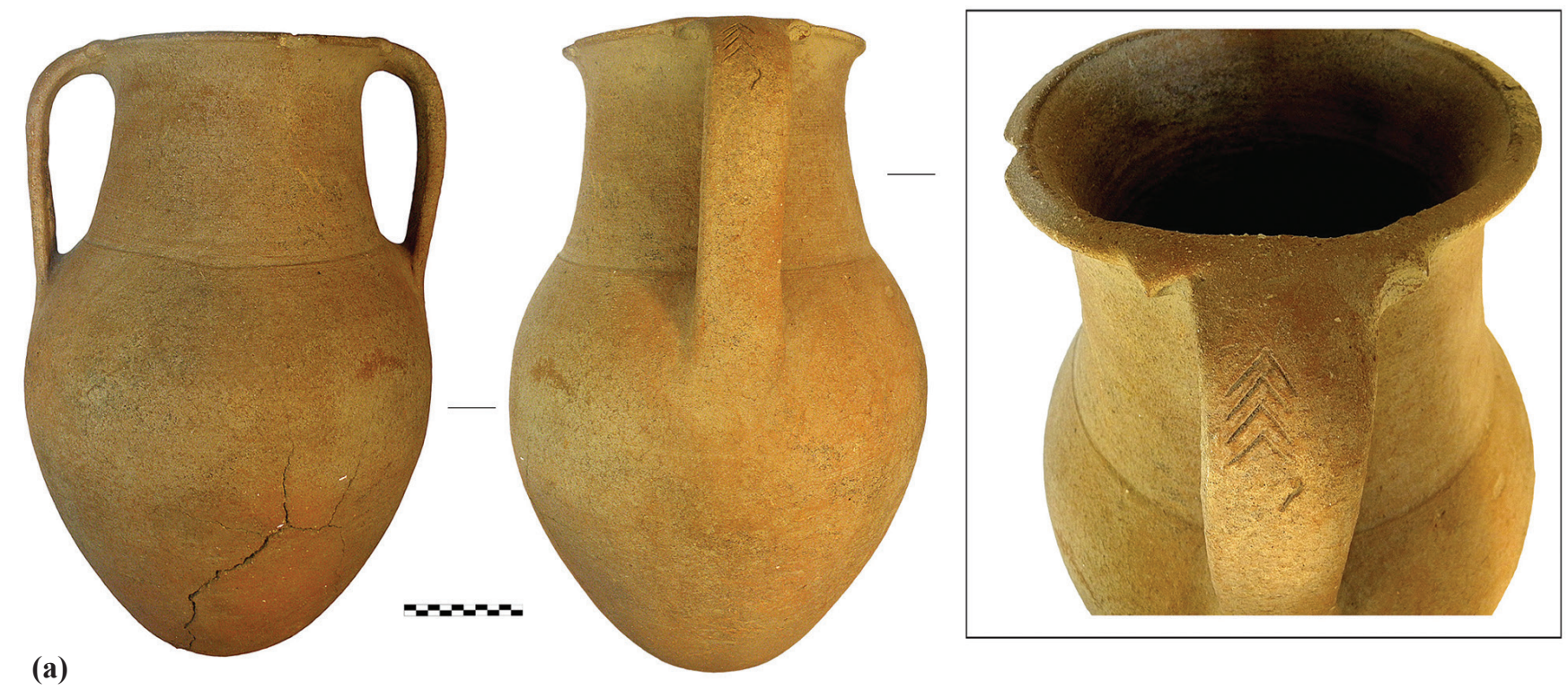

(a)

(b)

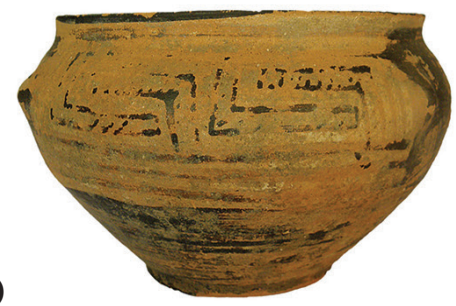

(c)

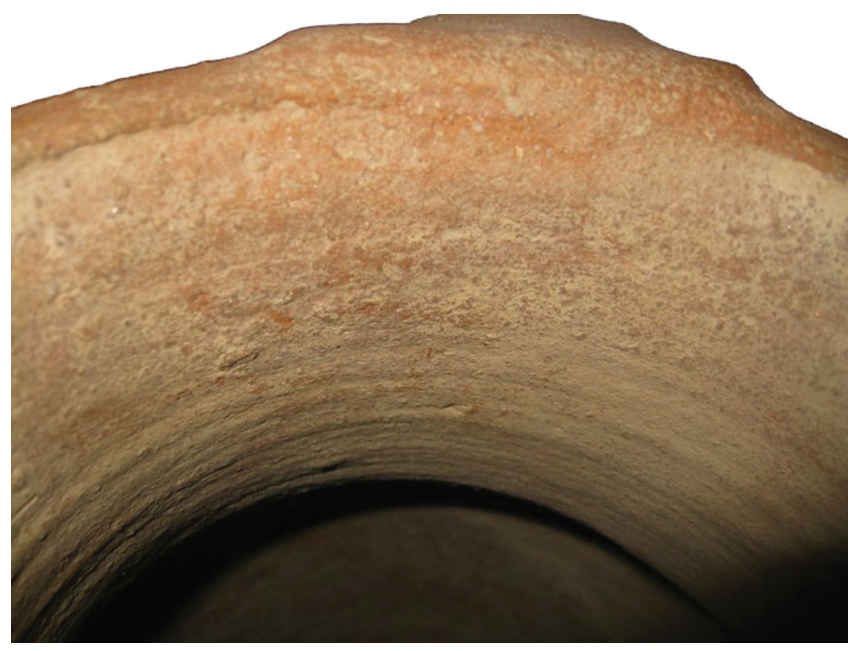

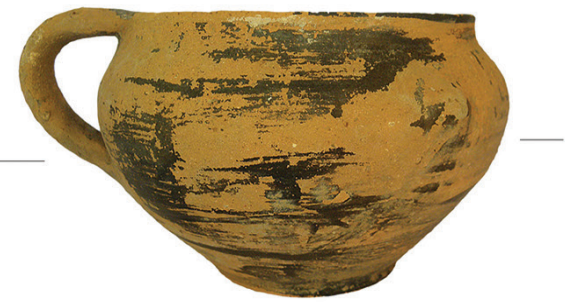
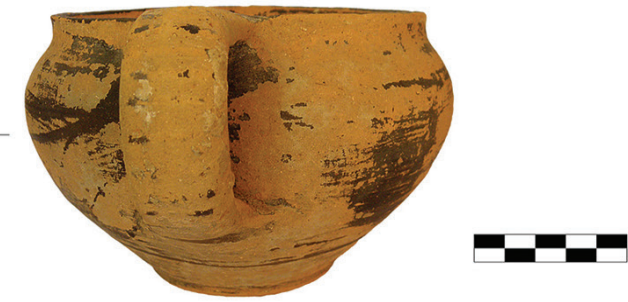

(d)

Figure 6. Tsikalario. Low Tumulus 6, Area A: a) Coarse amphora (MN 3825) and b) the fine kyathos (MN 3826) discovered inside. In the interior of the amphora MN 3825 on both c) the neck and d) the lower body there are horizontal ridges, while the exterior neck-surface preserves horizontal striations. Photographs by X. Charalambidou and D. Nenova.

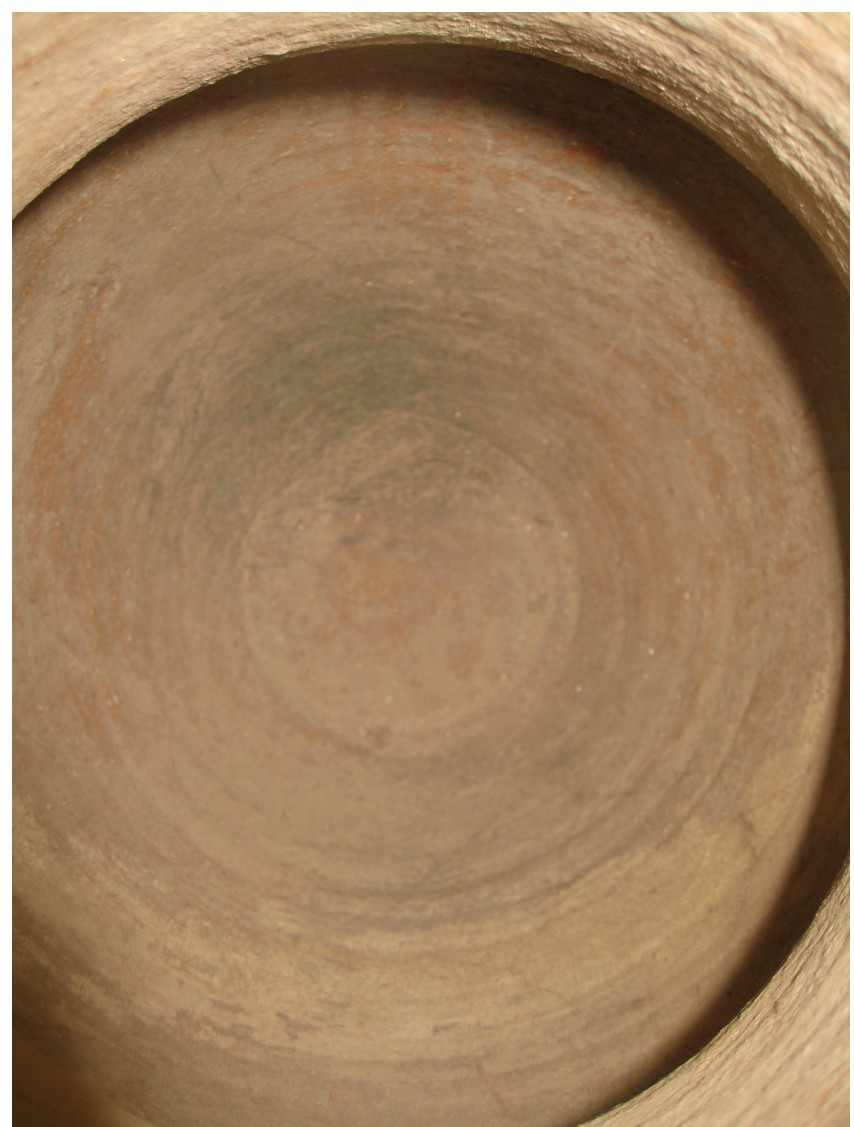


Figure 7. Tsikalario. Geometric coarse jar with tripod base (tripod jar) (MN 3831). Photograph by D. Nenova.

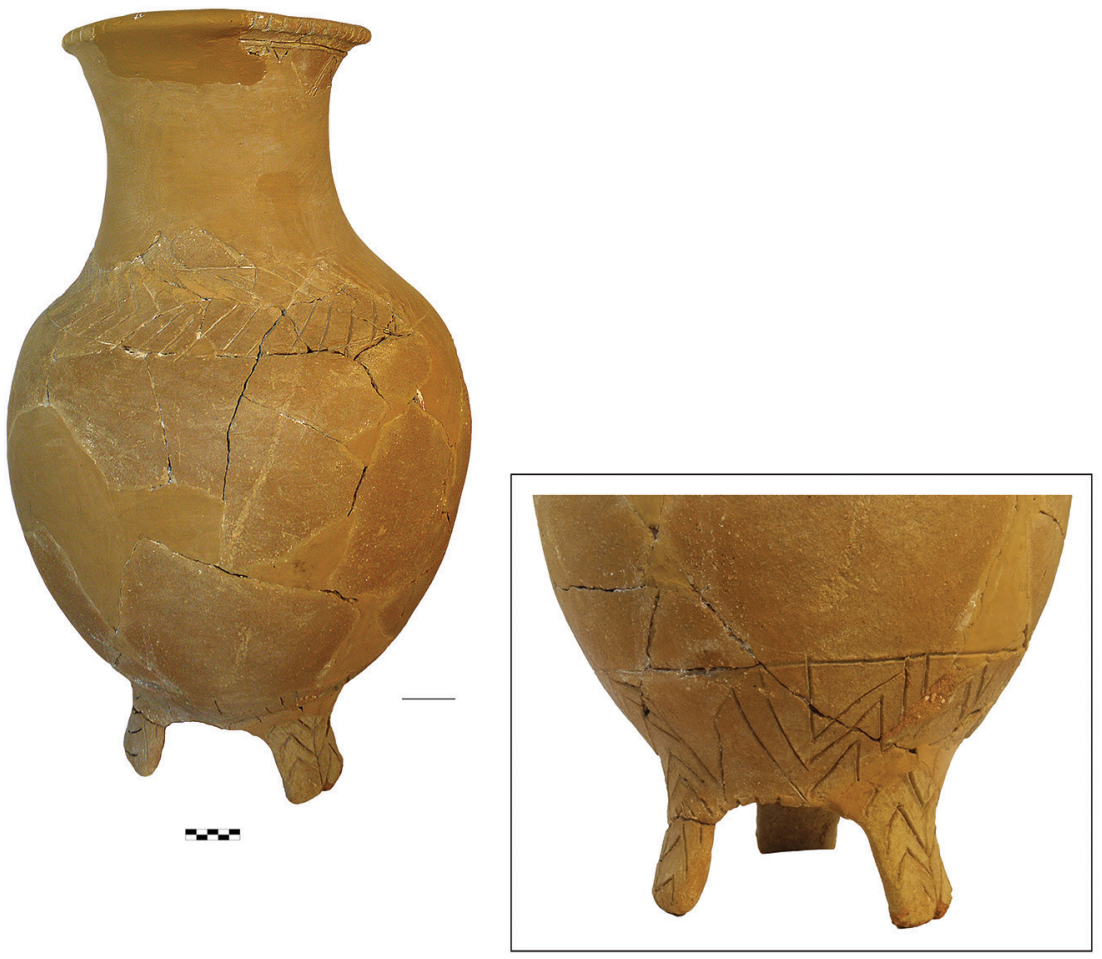

and in the cemeteries of the harbour town of Naxos; some of these pots have a burnished surface and some do not, but none have horizontal ridges or striations (Charalambidou 2021) (e.g., Figure 8a-b). Macrotrace documentation as well as X-ray analysis will be conducted on the coarse amphora from the centre of low Tumulus 6 (and on other pots from this tumulus and from other Tsikalario funerary contexts) to understand further its forming and finishing techniques, ${ }^{15}$ since the observed regularity and the presence of parallel, horizontal striations, as they appear on $\mathrm{MN} 3825$, can be polysemic features, i.e., they can result from different forming techniques (Courty and Roux, 1995, p.18; Berg, 2009, p.141; Lis et al., 2020, p.2).

It is, however, worth noting here a remark by London (personal communication) on the effect of using a rotational device for medium-large pots (as in the case of MN 3825), based on her research on the Troodos potters: "if one coilbuilds a small pot on a turntable and makes it spin, to allow two hands to work the clay, the potter gets not so fast revolutions for a short period of time. The wheel stops rotating. But if the potter coil-builds a largish jar the weight of the clay allows the rotation speed to increase and to continue spinning for a long period of time, giving you two hands to work and thin the clay. Here, turntable weight plays a role: heavier turntables can spin faster and for longer than a light weight turntable".

\footnotetext{
15 This combined documentation will begin from summer 2022 onwards (pandemic restrictions did not allow us to perform these analyses earlier in 2021).
}

The exterior periphery of low Tumulus 6 seems to have been used from the Middle Geometric II-Late Geometric I onwards through the Archaic period, serving to link the first generation of the dead with the later ones (Charalambidou, 2018, p.189). Coarse storage jars and amphorae and cooking jugs are used there for enchytrismoi and/or funerary rituals. Pots from the periphery of the tumulus that can be dated probably to the Middle Geometric and Late Geometric (I?) periods include a hand-made tripod jar with incised decoration and a hand-made handleless jar; significant for our discussion is another coarse storage amphora (MN 3800) of the same shape and possibly of the same or similar technique (i.e., the assistance of a rotational device is here evident as well) as the coarse amphora MN 3825 from the centre of this structure (Figure 9a-b).

Based on the types of funerary structures and the vessel forms used in the context of the cemetery, what I currently observe are two chronological phases which are also informative for changes in the manufacture of coarse wares (fine wares continue to be wheel-made throughout in their vast majority): in the first phase (first half to third-quarter of the $8^{\text {th }}$ century BC), which roughly coincides with the period of use of the interior of most of the low tumuli at Tsikalario and the beginning of the use of their exterior perimeters, hand-made potting traditions prevail and the predominant coarse shapes are hand-made jars and amphorae, which also share some similarities in form. This first phase gradually seems to come to an end, roughly when some sort of rotational device(s) is noticed for the manufacture of the two coarse amphorae 

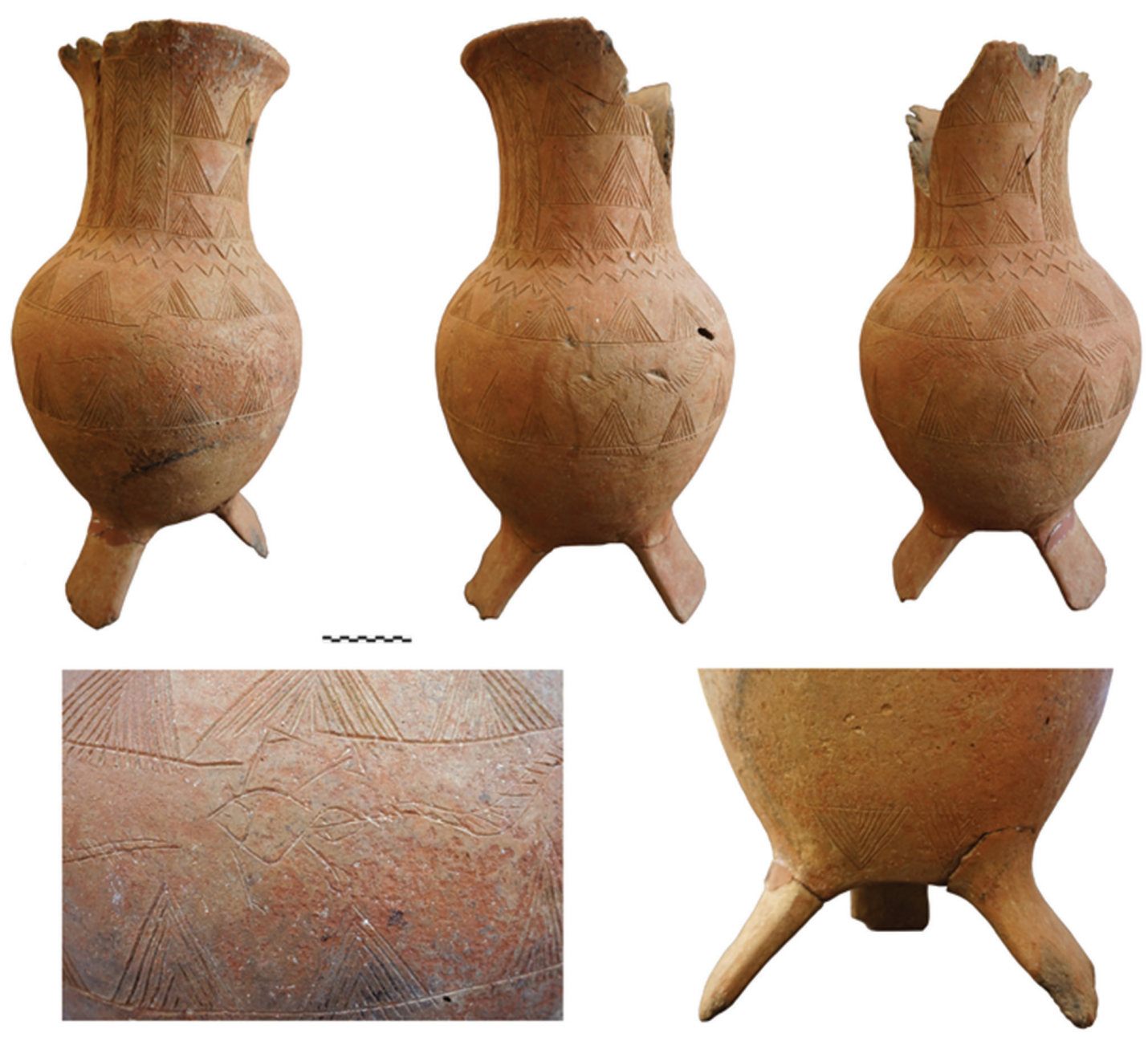

(a)

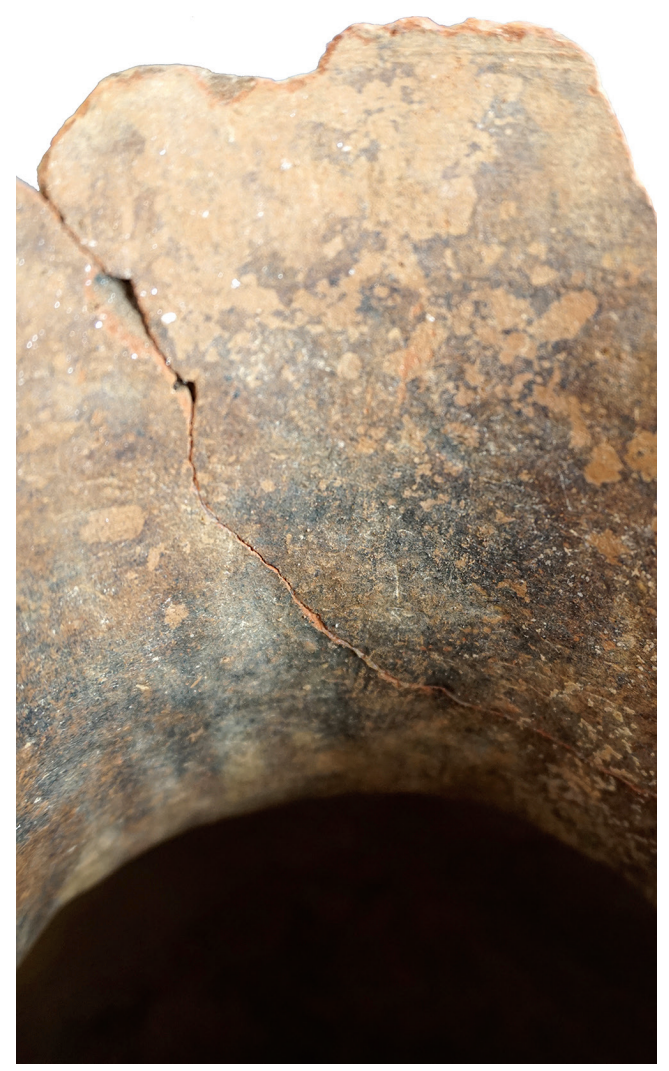

(b)

Figure 8. a) Geometric tripod jar from Agios Ioannis Apeiranthou, inv. 1043; b) Interior neck surface with no horizontal ridges. Photographs by $\mathrm{X}$. Charalambidou and N. Sepetzoglou. 


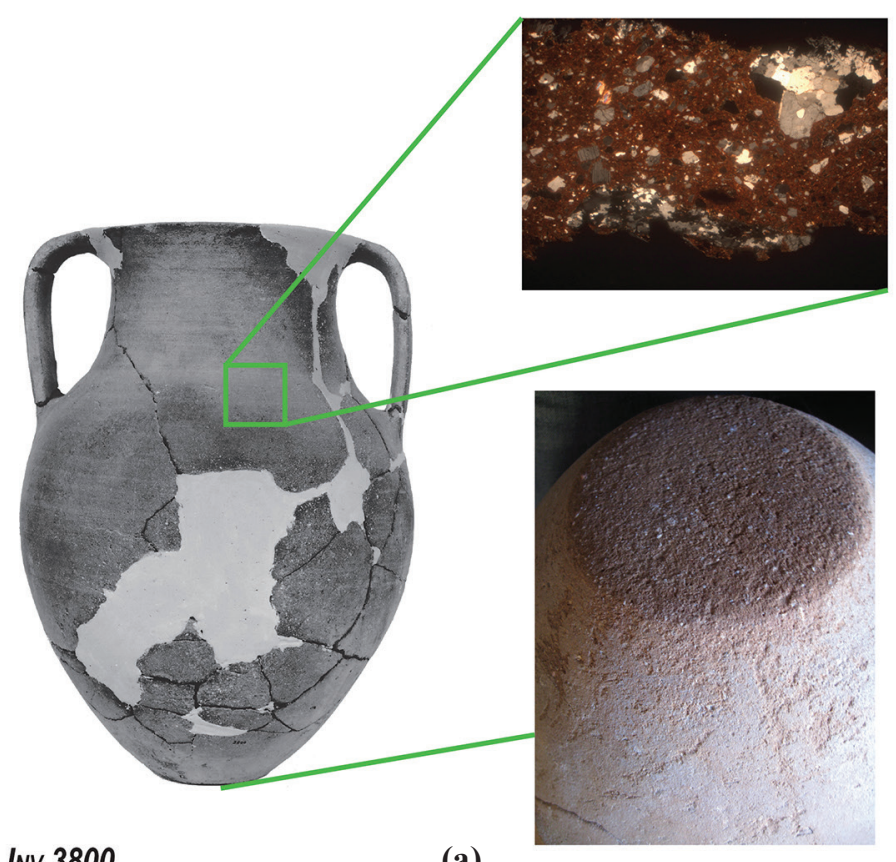

INv.3800 (a)

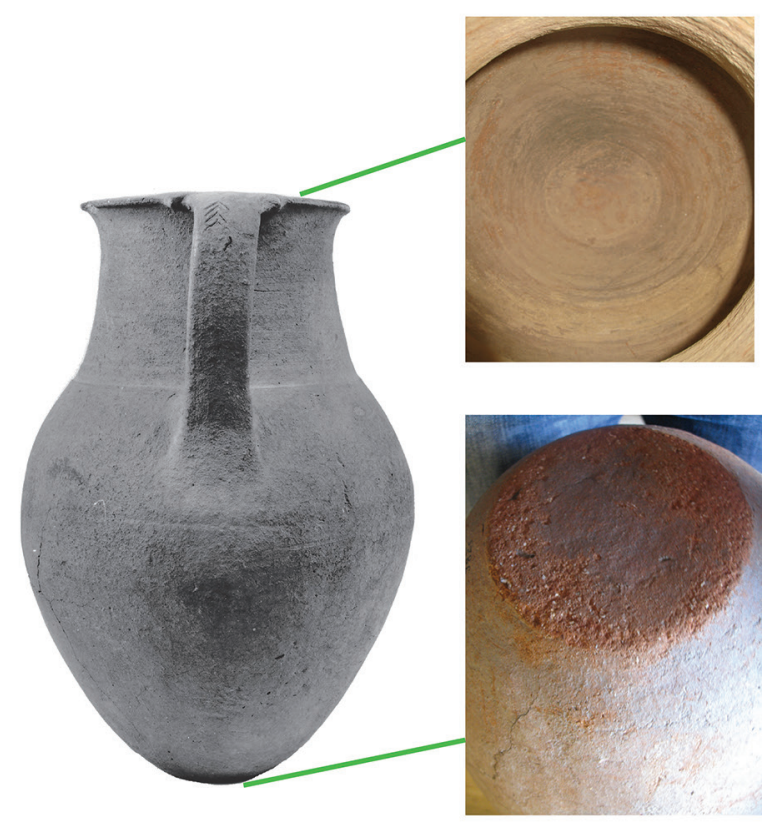

INV.3825

(b)

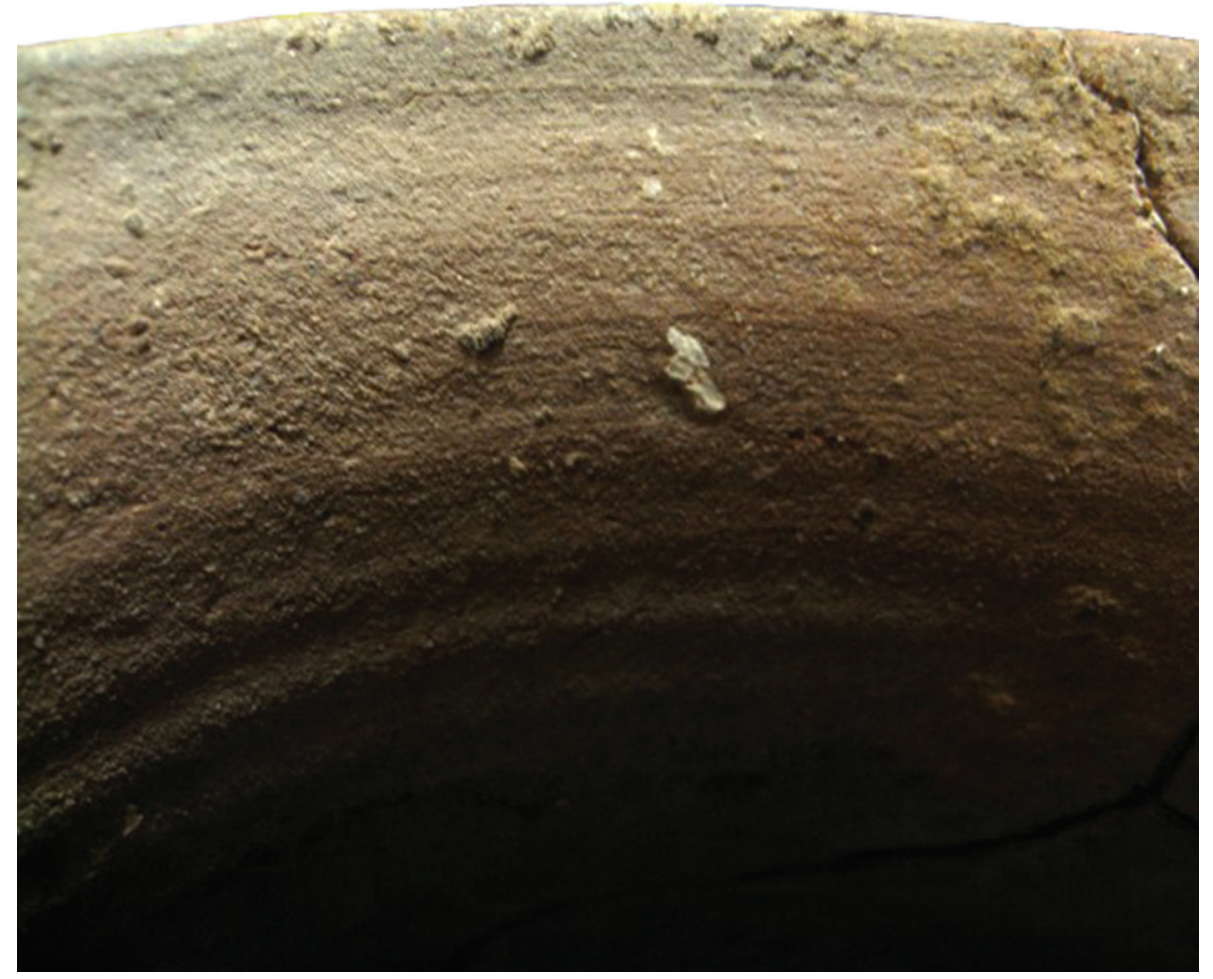

Figure 9. a-b) Tsikalario. Coarse storage amphora from the exterior of low Tumulus 6 (MN 3800) of the same shape and possibly of the same or similar technique as the coarse amphora MN 3825 from the centre of this structure. Figure by X. Charalambidou. 

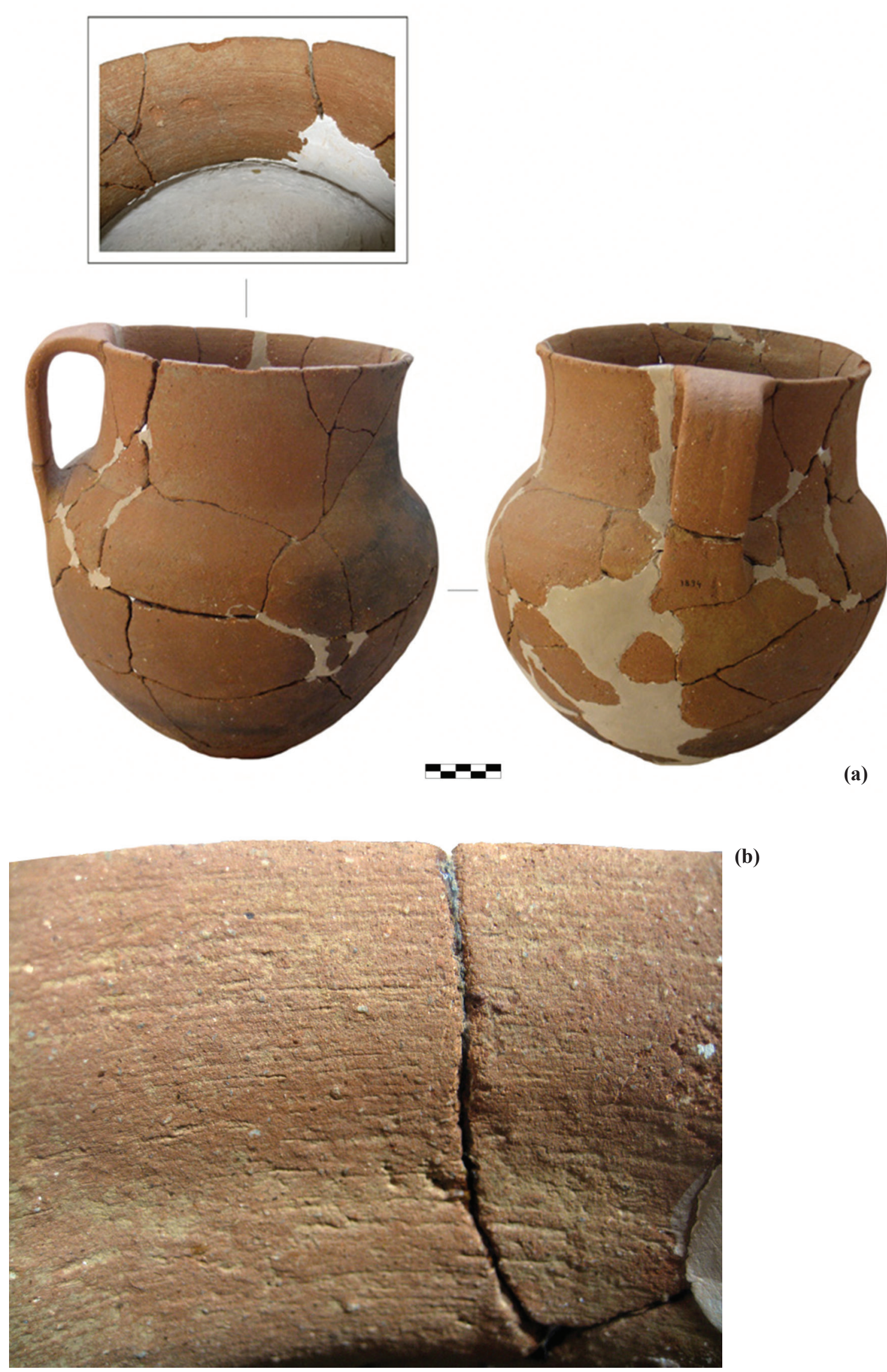

(b)

Figure 10. a-b) Tsikalario. One-handled cooking jug, showing finish on some sort of rotational device. Photographs by X. Charalambidou and D. Nenova. 


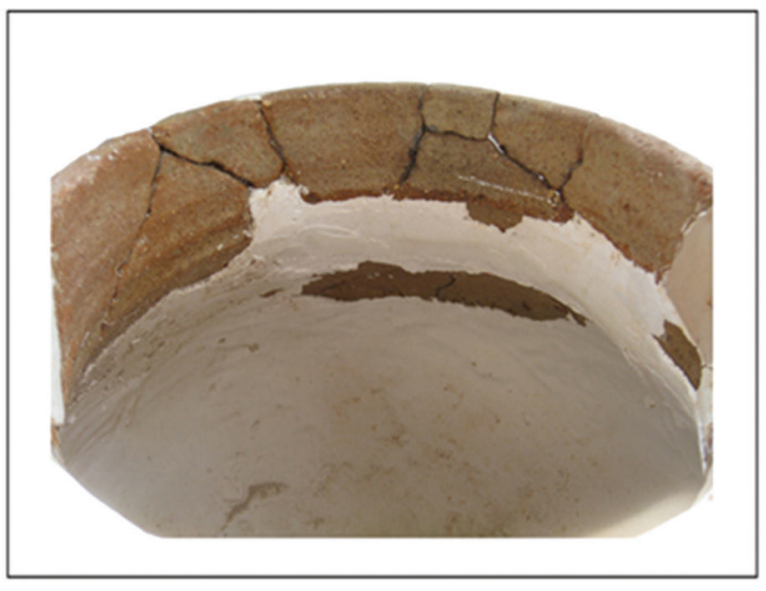

(a)

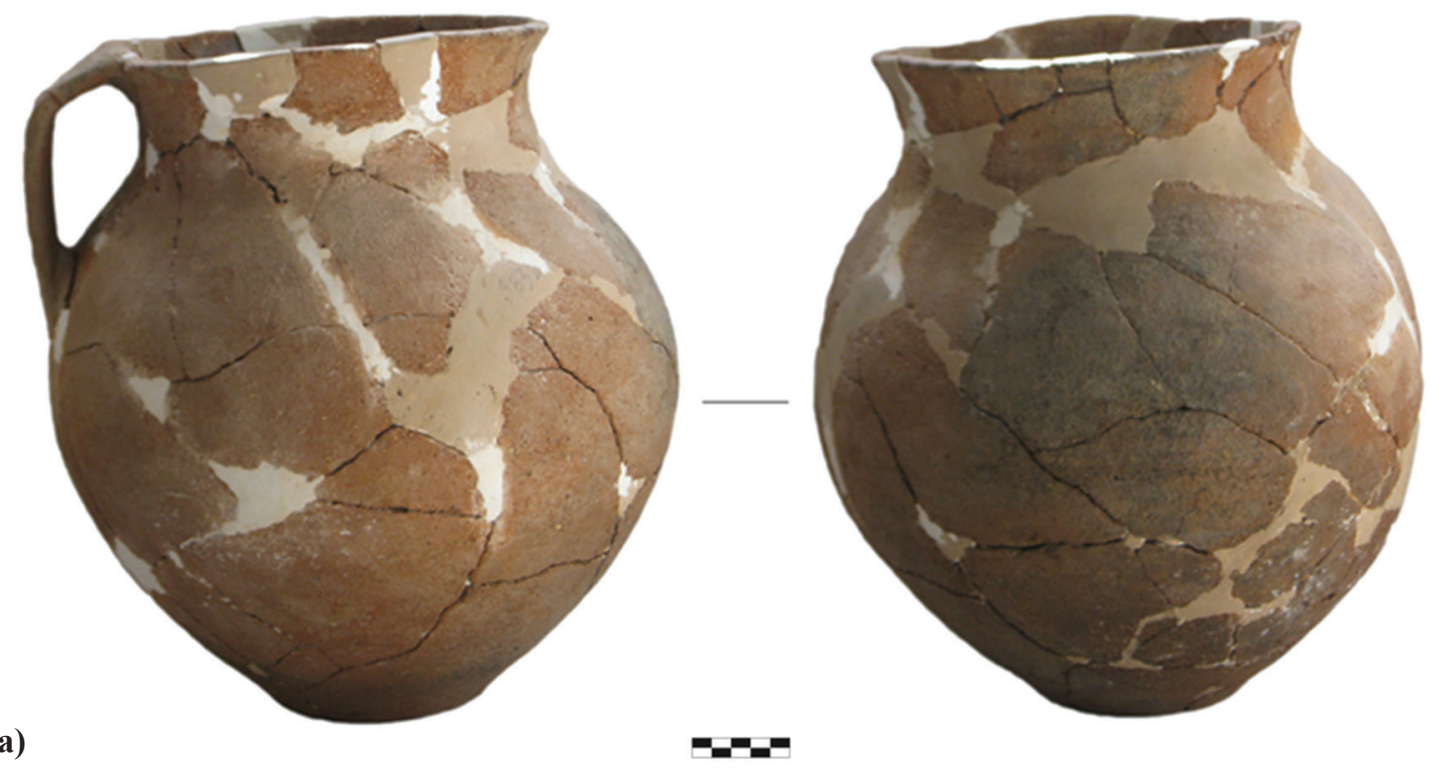

(b)

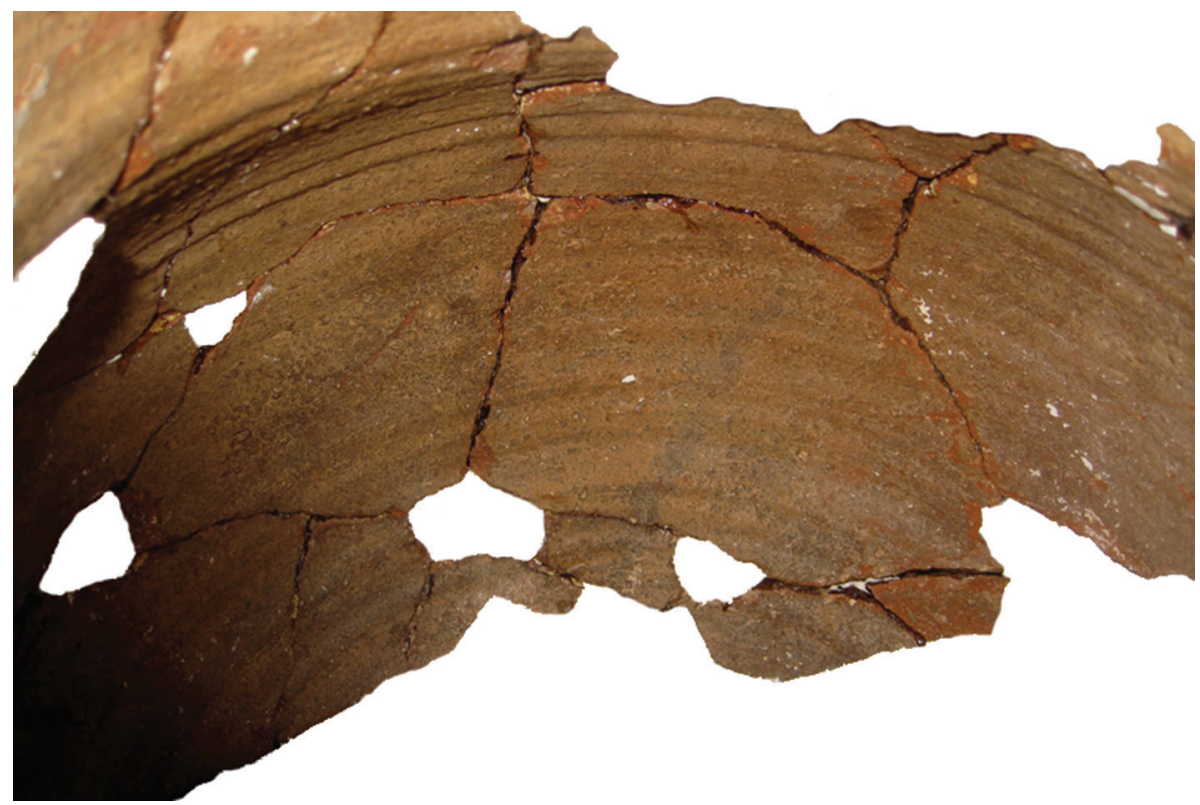

Figure 11. a-b) Tsikalario. One-handled cooking jug, with stronger evidence of wheel rotation in its forming. Photographs by X. Charalambidou and D. Nenova. 


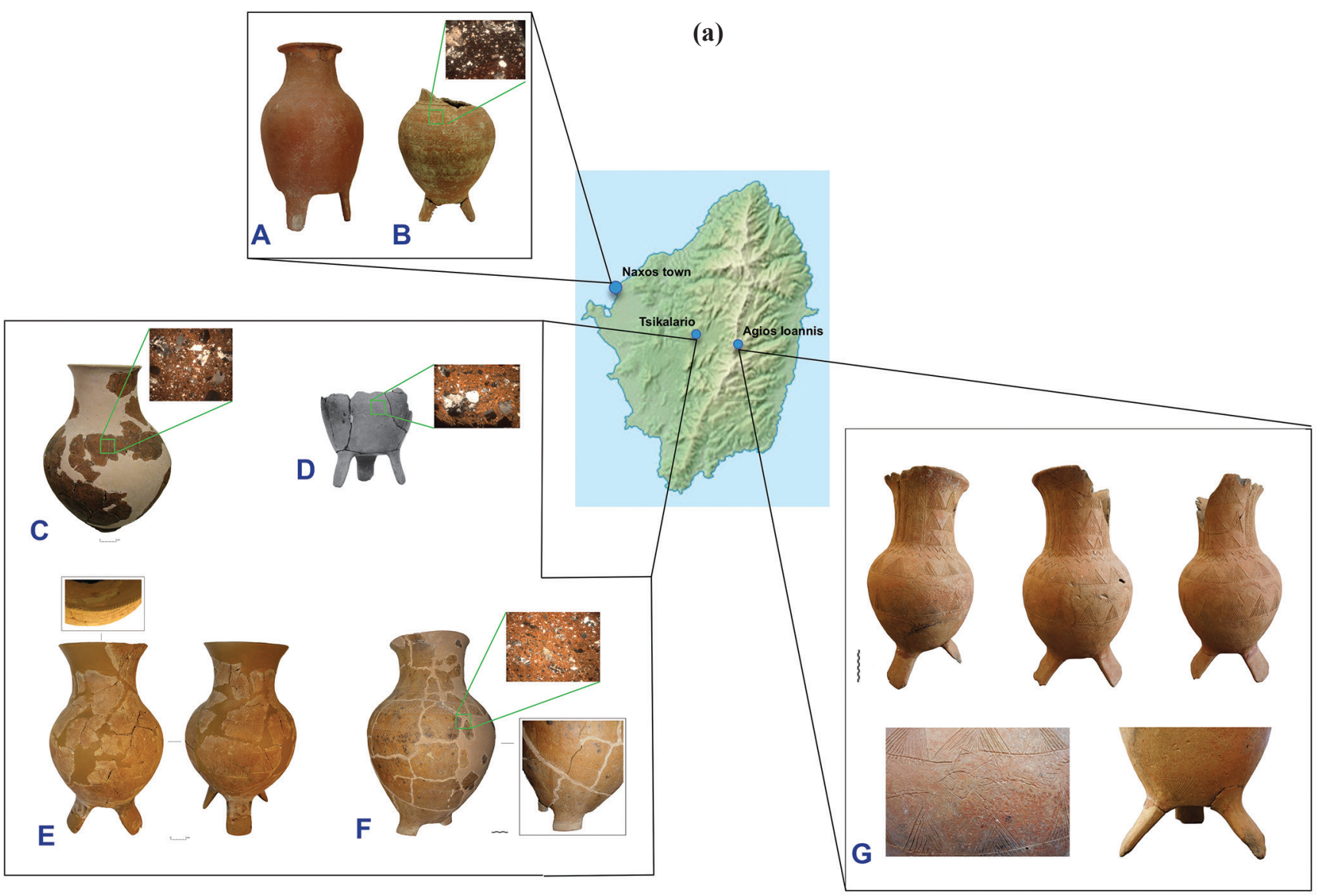

(b)

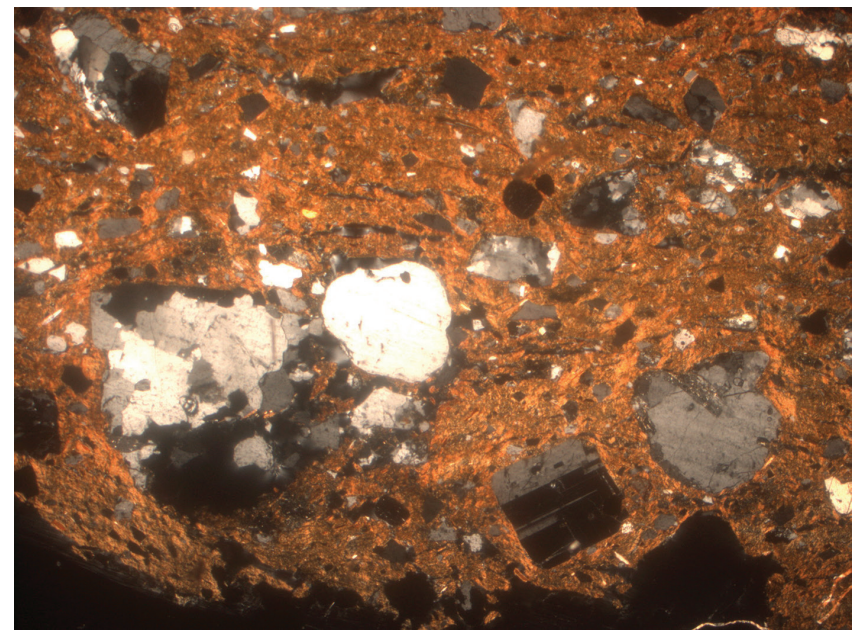

(c)

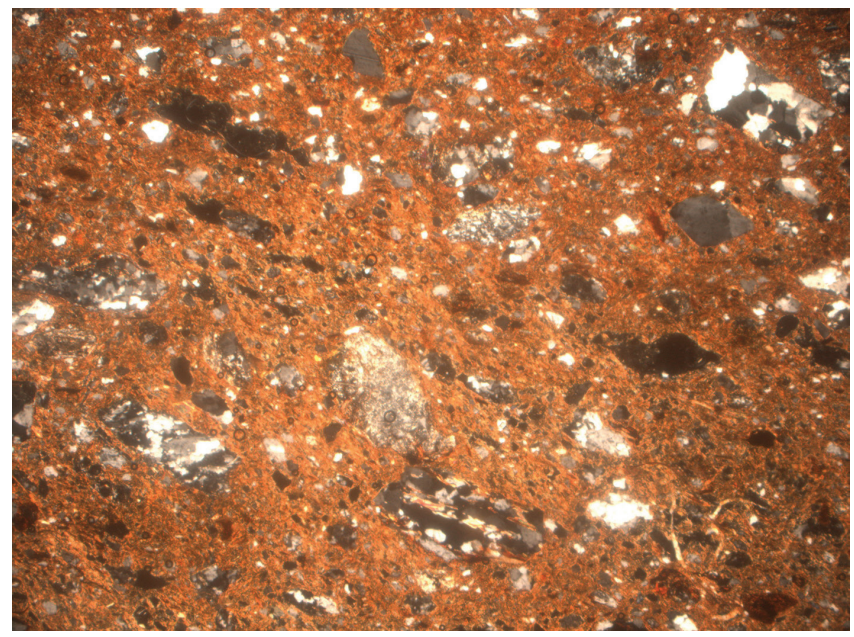

Figure 12. a) Coarse storage jars from Naxos town (harbour town of Naxos), Tsikalario and Agios Ioannis Apeiranthou in inland Naxos, some with photomicrographs (XPL/field of view $5.5 \mathrm{~mm}$ ) of their fabrics; b) Photomicrograph in greater detail (of example D; XPL/field of view $5.5 \mathrm{~mm}$ ); c) Photomicrograph in greater detail (of example F; XPL/field of view $5.5 \mathrm{~mm}$ ). Figure by X. Charalambidou.

from low Tumulus 6 (MN 3825, 3800). During the latter phase of use of the Tsikalario cemetery (mainly last quarter of the $8^{\text {th }}$ century $\mathrm{BC}$ into, at least, the Archaic period), when the peripheries of some low tumuli continue to be used and other more irregular funerary stone structures or enclosures are built within the necropolis, a shift in the use of shapes is also observed, with the prevalence now being for cooking pots, especially cooking jugs, which show a diversity of primary and secondary roughouts and preform stages of vessel formation. The cooking jugs of the second phase show various levels of use of rotational devices. Several have only their finish achieved on some sort of rotational device (e.g., 
Figure $10 \mathrm{a}-\mathrm{b})$; for others there is stronger evidence of wheel rotation for their manufacture (e.g., Figure 11a-b).$^{16}$

Petrographic and WD-XRF analyses conducted at the Fitch Laboratory of the British School at Athens by the author of the paper, Evangelia Kiriatzi and Noemi Müller on fine and coarse wares from the Tsikalario cemetery and the Plithos burial ground at the harbour town of Naxos have yielded some stimulating first results regarding the coarse wares. Among the Naxian hand-made coarse pots analysed, the vast majority were storage jars from Tsikalario and Plithos with a tripod foot or plain base; a vessel form, as mentioned above, that was circulating in both the coastal and inland parts of the island (Figure 12a) (recently Charalambidou, 2018, passim; Charalambidou, 2021). For these a main fabric group seems to have been used (see photomicrographs in Figure 12a [B$\mathrm{D}]$ and in greater detail example [D] in Figure 12b), which can be associated with the dominant granite-granodiorite intrusion in the western region of Naxos (where Naxos town is also located). ${ }^{17}$ Within this group, variation reflects some heterogeneity in the sourcing of raw materials. But this is not the only fabric used for the manufacture of hand-made jars. Petrographic and elemental analyses of the Naxian handmade jar from Tsikalario, MN 3839, indicate a distinctly different fabric, characterised by schist and polycrystalline quartz rock fragments (photomicrograph in Figure 12a $[\mathrm{F}]$ and in greater detail in Figure 12c). ${ }^{18}$ This fabric is compatible with the local geology of central and eastern Naxos (the Tsikalario cemetery is situated in the central part).

These findings imply the existence of pottery production sites in different parts of the island, with some products (of the main fabric group of jars) from the western part reaching inland Tsikalario. Either the latter jars were traded/ exchanged or people brought them when they moved to the interior (as a result of intermarriages?). In addition to these Naxian coarse wares, fine ware imports, probably first arriving in the harbour town of Naxos, from regions such as Paros, Attica, and even Cyprus, were also reaching Tsikalario (Charalambidou 2018, passim). Such finds, both regional from the island of Naxos and imported objects from other Aegean sites, indicate an increasing intra- and inter-island connectivity and mobility of goods in the $8^{\text {th }}$ century BC.

Equally important is the fact that even though three samples of storage amphorae from low Tumulus 6 at Tsikalario have fabrics characterised by polycrystalline rock fragments, they are yet distinctly different, petrographically

\footnotetext{
${ }_{16}$ The possibility that there is no linear development in the manufacture of Naxian coarse pots is being examined.

17 This coarse, low calcareous fabric (average $\mathrm{CaO}$ content $1.5 \%$ ) includes metamorphosed rock fragments, granites, and associated minerals such as amphibole, epidote group minerals and sphene, with or without volcanic rock fragments. The coarse and fine fractions contain quartz, feldspar grains, gold (biotite) and white mica (Charalambidou et al., 2017, pp.123-124).

18 This fabric includes (biotite+white mica) schist and polycrystalline quartz rock fragments and also biotite, white mica and rare epidote group minerals. It is low calcareous with higher $\mathrm{Cr}, \mathrm{Ni}$ and $\mathrm{Mg}$ concentrations, quite unlike the other analysed Naxian coarse jars (Charalambidou et al., 2017, pp.124-125)
}

and chemically, from the jar MN 3839. Among them is the amphora MN 3800 (Figure 9a), which together with amphora MN 3825 provided early evidence of the use of a rotational device on EIA Naxian coarse wares. More storage amphorae as well as cooking jugs from Tsikalario will be analysed petrographically and chemically to understand intra-island variability, but it is interesting to note that, so far, it seems that a rotational device for the manufacture of the amphora MN 3800 may have been employed for a pot using a clay similar to those utilised for the making of hand-made storage amphorae from Tsikalario.

\section{First discussion: patterns of Naxian interactions}

In the EIA, and especially in the Geometric period, in addition to the prominent harbour town of Naxos, dispersed communities in both coastal and inland regions of the island are documented on Naxos, judging mainly by evidence extrapolated from cultic and burial sites. ${ }^{19}$ From the Geometric period onwards, regional surveys on Naxos also indicate a demographic growth in the Naxos countryside. ${ }^{20}$ Alongside documented settlement dispersion, the study of pottery manufacturing behaviours allows for a detailed understanding of social dynamics.

Preliminary results on the variability of fabrics at the cemetery of Tsikalario implies that several communities on the island were involved in pottery manufacture. That various production sites were probably active in the coastal and inland parts alike is also shown by ethnographic research on Naxos. Betty Psaropoulou documented the existence of pottery kilns both in the harbour town of Naxos and in inland Naxos; interestingly most of the preserved $19^{\text {th }}-20^{\text {th }}$-century AD kilns were located in central Naxos; one comes from Tsikalario, while the largest concentration appears south of Tsikalario. ${ }^{21}$ They may indicate the existence of natural clay resources in the interior of Naxos, not far away from the area of the ancient Tsikalario cemetery.

On EIA Naxos, the process by which a rotational device was incorporated into the existing hand-making coarse-ware potting tradition is of key importance. As I mentioned above, observed evidence of this use so far is known at Tsikalario (low Tumulus 6) from (at least) the middle or third-quarter of the $8^{\text {th }}$ century $\mathrm{BC}$ onwards. What we are witnessing are possible changes to hand-building traditions during these years, in which existing multi-stage techniques continue to be used, but rotational devices were also gradually introduced for various stages of the manufacturing process. Did the impetus for the incorporation of rotational devices for coarse

\footnotetext{
19 Recently summarised in Charalambidou, 2018, pp.143-149. To date, preserved residential areas dating to the EIA have not been uncovered.

${ }^{20}$ E.g., research by Érard-Cerceau et al. (1993) on the valley of Engares.

21 Psaropoulou, 2005, Figure 6. They come from Tsikalario, Monitsia, Filoti and Apeiranthos, while the largest concentration appears (south of Tsikalario) in the areas of Damalas, Timios Stavros, Kousoulou, Stous Kipous, Maroudia, Agioi Anargyroi and Anemomyloi.
} 


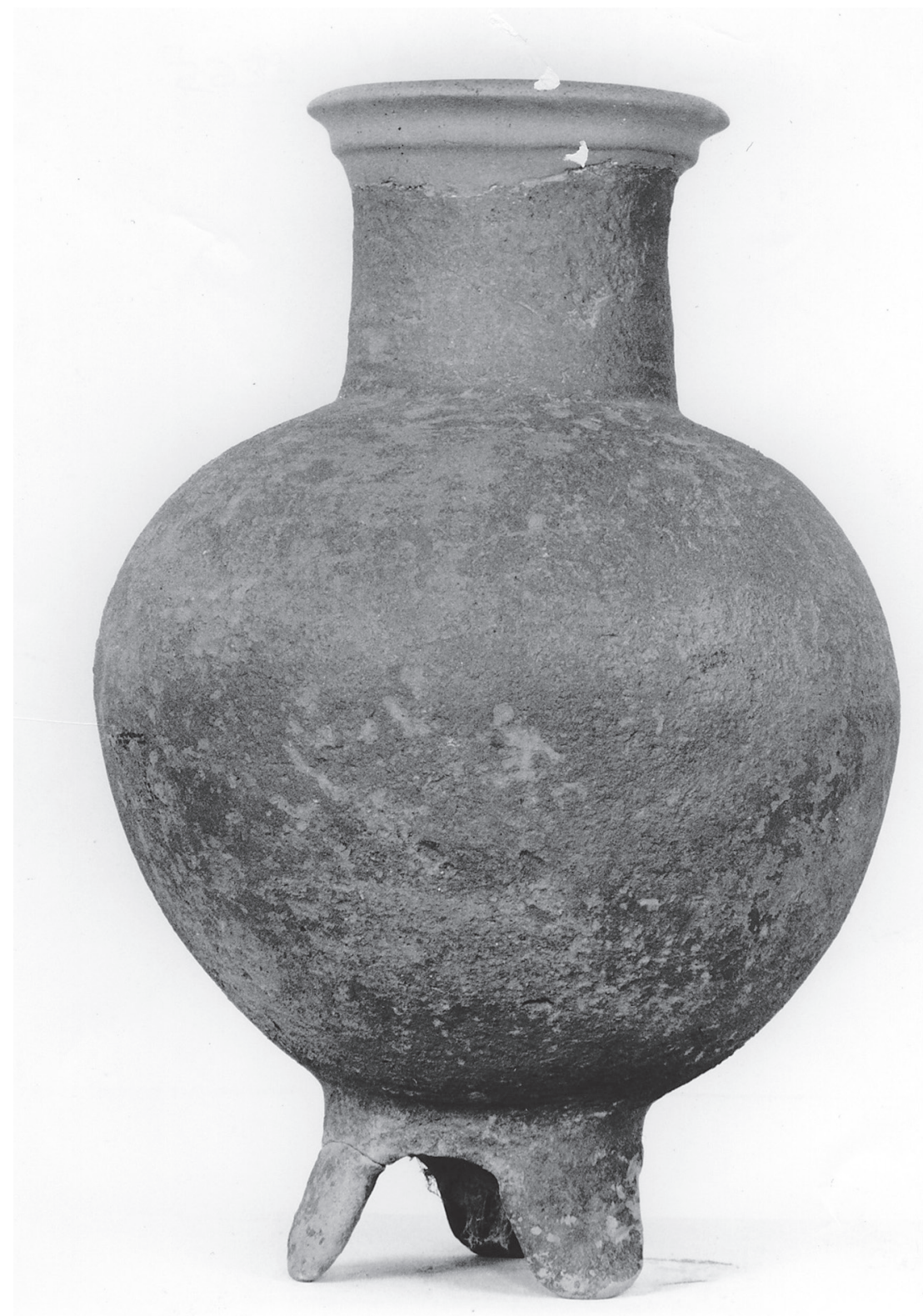

Figure 13. Tsikalario. Geometric fine/ semi-fine closed vessel with a tripod base (MN 3943). Photograph by I. Iliadis.

vessels come from cross-tradition transmission on Naxos, especially if we consider that there was a significant body of potters who were working with wheels to make fine wares? Artisanal interplay may also be implied by certain artefacts on EIA Naxos. One such from Tsikalario concerns a Naxian (possibly Middle Geometric) fine/semi-fine closed vessel with a tripod base (Figure 13). The shape of its foot seems to have been influenced by the form of the Naxian coarse tripod jar (e.g., Figures 7, 8 and 12a). ${ }^{22}$ Another example comes from the Naxian pithoi production of the last decades of the $8^{\text {th }}$ into the $7^{\text {th }}$ centuries BC (Simantoni Bournia, 1990; 2004). At the outset of their production, their sharing or adoption of some stylistic features with artisans producing coarse-

\footnotetext{
${ }^{22}$ One more fine-ware painted pot from the Plithos burial ground, exhibited at the Archaeological Museum of Naxos, bears such a tripod base.
}

ware jars, can offer further insight on interactions among producers (Charalambidou, 2021). The cross-fertilisation we begin to observe among ancient Naxian potters - tool, form and stylistic transmission - especially in the $8^{\text {th }}$-century - fits well with other patterns of interconnectivity evident on the island during the same century, especially the denser occupation patterns which offer evidence for demographic growth (see above; and also, Charalambidou, forthcoming).

Interactions among potters may have transcended potting communities within the island and may have reached out to other Cycladic communities. Apart from Naxos, wheel rotation on coarse wares has been documented by McLoughlin on Andros, at the Geometric settlement of Zagora among the pottery used by the occupants of the Zagora houses during the last quarter of the $8^{\text {th }}$ century BC (McLoughlin and Paspalas, forthcoming; see also McLoughlin, 2011). First 


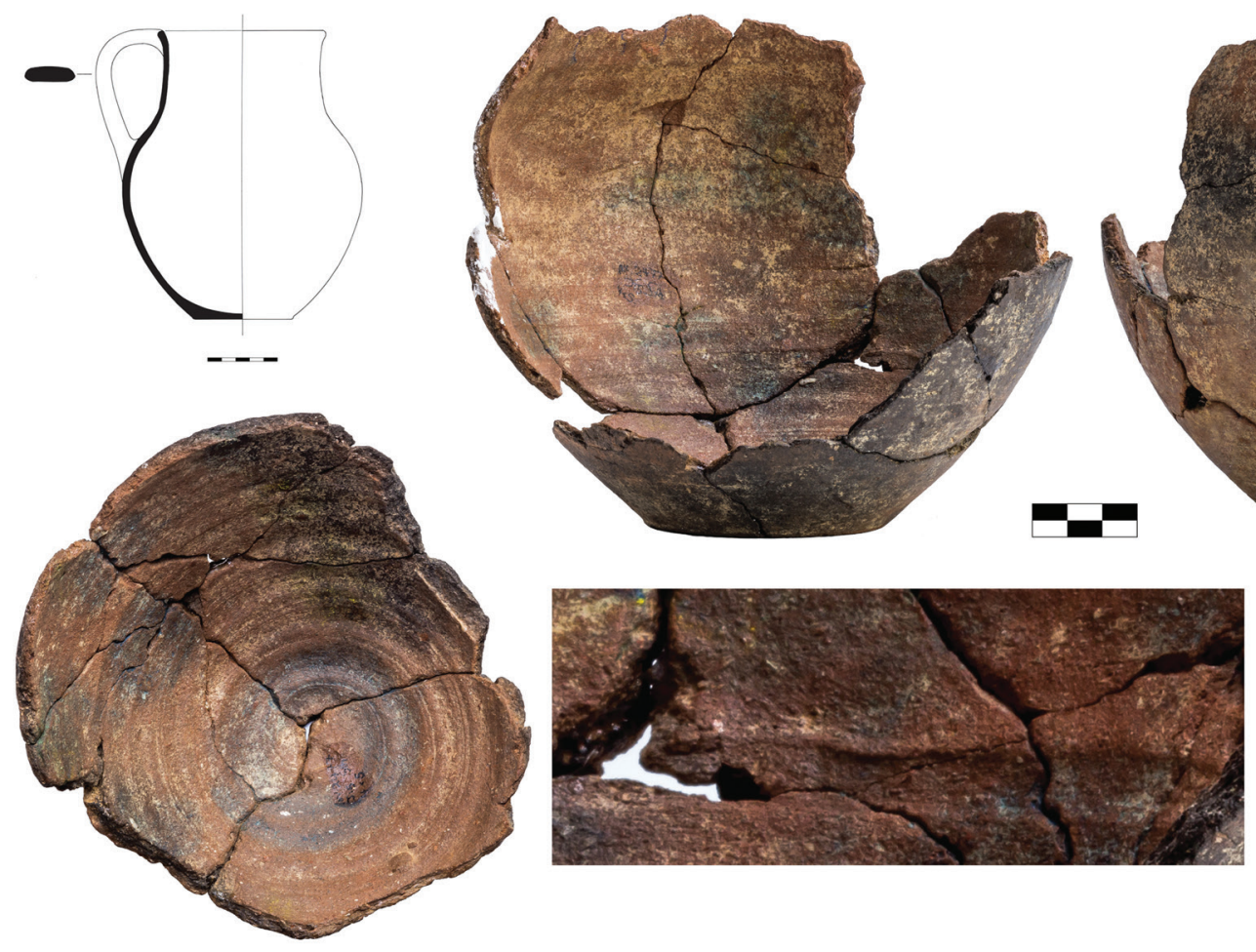

Figure 14. Geometric cooking jug from the settlement of Zagora on Andros. Figure by B. McLoughlin and B. J. Miller.

comparisons of the two traditions (Naxian and Andriot), which are unquestionably independent, indicate that wheelshaping became an integral part of the Naxian tradition from at least the middle or the third-quarter of the $8^{\text {th }}$ century $\mathrm{BC}$ onwards, whereas the Andriot tradition is grounded in the drawing technique, with the incorporation of wheelshaping into existing practices only at the end of the EIA (e.g., Figure 14). Since the Zagora potters had achieved the same, for a restricted shape range, in the last decades of the $8^{\text {th }}$ century, the incorporation of wheel use into the existing Zagora tradition raises the question of artisanal interplays between Naxos and Andros.

\section{Summary}

On Naxos, coastal-hinterland links are well exemplified during the EIA, especially in the $8^{\text {th }}$ century $\mathrm{BC}$, when population growth probably occurs with the establishment (and archaeological visibility) of more sites in the hinterland. Inland valleys seem to have created communication arteries connecting the two parts (Charalambidou, forthcoming). Ceramic products circulating from the harbour town of Naxos, and the western coastal part of the island in general, to inland Naxos and vice versa (e.g., agricultural products) may have flowed along these arteries. The use of the rotational device on coarse wares, evident at the cemetery of Tsikalario, may be part of a wider picture of interactions among potters working on the island. Detailed documentation of forming and finishing techniques which will begin within 2022, aided by a larger number of samples to be archaeometrically analysed, is expected to enrich our understanding of differentiations among local potting traditions but also of intra- and inter-island connectivity. This in turn will help reveal the socioeconomic conditions that facilitated networks of apprenticeship by local communities in urban and rural settlements on EIA Naxos.

\section{Acknowledgements}

My sincere thanks go to Beatrice McLoughlin, Gloria London, Jan Paul Crielaard and Ian Whitbread for helpful discussions on topics relevant to the purposes of this article. The study is currently conducted in the frameworks of the NWO-funded Melting Pot Project at Vrije Universiteit Amsterdam (VC.GW17.136).

\section{References}

ABELL, N., and HILDITCH, J., 2016. Adoption and Adaptation in Pottery Production Practices: Investigating Cycladic Community Interactions Through the Ceramic Record of the Second Millennium BC. In: E. Gorogianni, P. Pavúk, L. Girella, eds. Beyond Thalassocracies: Understanding Processes of Minoanisation and Mycenaeanisation in the Aegean. Oxford: Oxbow Books, pp. 155-171.

ABUlAFIA, D., 2010. The Great Sea. A Human History of the Mediterranean. Oxford: Oxford University Press. 
ALBERO SANTACREU, D., 2017. The Times They Were a-Changing: Cultural Encounters, Social Transformations and Technological Change in Iron Age Hand-made Pottery from Mallorca (Spain). Journal of Mediterranean Archaeology, 30(1), 105-131.

BERG, I., 2007a. Meaning in the Making: The Potter's Wheel at Phylakopi, Melos (Greece). Journal of Anthropological Archaeology, 26(2), 234 252.

BERG, I., 2007b. Negotiating Island Identities: The Active Use of Pottery in the Middle and Late Bronze Age Cyclades. Piscataway, NJ: Gorgias Press LLC.

BERG, I., 2009. X-Radiography of Knossian Bronze Age Vessels: Assessing our Knowledge of Primary Forming Techniques. Annual of the British School at Athens, 104, 137-173.

BERG, I. 2015. Potting Skill and Learning Networks in Bronze Age Crete. In: W. Gauss, G. Klebinder-Gauss, C. von Rüden, eds. The Transmission of Technical Knowledge in the Production of Ancient Mediterranean Pottery, Proceedings of the International Conference at the Austrian Archaeological Institute at Athens, 23 $3^{\text {rd }}-25^{\text {th }}$ November 2012. Wien: Österreichisches Archäologisches Institut, pp. 17-34.

BONNIER, A., 2016. Harbours and Hinterland Networks by the Corinthian Gulf, from the Archaic to the Early Hellenistic period. In: K. Höghammar, B. Alroth, A. Lindhagen, eds. Ancient Ports. The Geography of Connections. Proceedings of an International Conference at the Department of Archaeology and Ancient History, Uppsala University, $23^{\text {rd }}-25^{\text {th }}$ September 2010. Uppsala: Acta Universitatis Upsaliensis, pp. 65-94.

BROODBANK, C., 2000. An Island Archaeology of the Early Cyclades. Cambridge: Cambridge University Press.

BROODBANK, C., 2013. The Making of the Middle Sea: A History of the Mediterranean from the Beginning to the Emergence of the Classical World. London: Thames and Hudson.

CHARALAMBIDOU, X., 2008-2009. The Pottery from the Early Iron Age Necropolis of Tsikalario on Naxos. Preliminary Observations. AIONArch, 15-16, 57-69.

CHARALAMBIDOU, X., 2010-2012. Keramiká evrímata apó ti nekrópoli tou Tsikalarioú sti Náxo. Paratirísis skhetiká me to taphikó perivállon kai ti khrísi ton angíon. Archaiognosia, 16, 149-186.

CHARALAMBIDOU, X., 2011. Quantitative Analysis of the Pottery from the Early Iron Age Necropolis of Tsikalario on Naxos. In: S. Verdan, T. Theurillat, A. Kenzelmann Pfyffer, eds. Early Iron Age Pottery: A Quantitative Approach, Proceedings of the International Round Table organized by the Swiss School of Archaeology in Greece (Athens, November 28-30, 2008), Oxford: BAR International Series, pp. 139-147.

CHARALAMBIDOU, X., 2017. Ceramics, Cultural Interconnections and Influences on Naxos. In: V. Vlachou, and A. Gadolou, eds. Térpsis. Studies in Mediterranean Archaeology in honour of Nota Kourou. Etudes d'archeologie, 10, Brussels: CReA-Patrimoine, pp. 375-392.

CHARALAMBIDOU, X., 2018. Iron Age Mortuary Practices and Material Culture at the Inland Cemetery of Tsikalario on Naxos: Differentiation and Connectivity, Annual of the British School at Athens, 113, 143-198.

CHARALAMBIDOU, X., 2021. Style and Function of Geometric Coarse Jars from Naxos: Examples from Inland and Coastal Regions of the Island. In: V. Lambrinoudakis, L. Mendoni, M. Koutsoumpou, T. Panagou, A. Sfyroera, X. Charalambidou, eds. Exokhos allon: Timitikós tómos yia tin Kathiyitria E. Simantóni-Mpourniá. Athens: Hellenic Organisation of Cultural Resources, Publications Directorate, pp. 147-162.

CHARALAMBIDOU, X., forthcoming. Migrating from Greece to Italy: Features of Euboean and Naxian Settlements before the Advent of and during the Early Iron Age Greek Diaspora to Italy. In: L. Caliò, E. Pappalardo, C. Rescigno, S. Todaro, eds. Skhimata. The City Beyond its Shape: Defining Cityscapes and their Functions: Urbanization and Society in the Pre-Classical Mediterranean World.

CHARALAMBIDOU, X., KIRIATZI, E., MÜLLER, N.S., 2017. Scales of Ceramic Analysis on Naxos (Cyclades). In: S. Handberg, and A. Gadolou, eds. Material Koinai in the Greek Early Iron Age and Archaic Period. Aarhus: Monographs of the Danish Institute at Athens, 22, pp. 109-132.

CHOLEVA, M., JUNG, R., KARDAMAKI, E., 2020. Working on the Potter's Wheel: Technological Insights into Mycenaean Pottery Production. Egypt and the Levant, 30, 219-282.

CONSTANTAKOPOULOU, C., 2007. The Dance of the Islands: Insularity, Networks, the Athenian Empire, and the Aegean World. Oxford: Oxford
University Press.

CONSTANTAKOPOUlOU, C., 2017. Aegean Interactions: Delos and its Networks in the Third Century. Oxford: Oxford University Press.

COURTY, M.A., and ROUX, V., 1995. Identification of Wheel Throwing on the Basis of Ceramic Surface Features and Microfabrics. Journal of Archaeological Science, 22, 17-50.

CRIELAARD, J.P., KLUIVING, S., CHARALAMBIDOU, X., GODEFROY, L., SHEIK, T., 2020. What Went into the Melting Pot? Land Use, Agriculture and Craft Production as Indicators for the Contributions of Greek Migrants and Local Inhabitants to the so-called Greek Colonization in Italy (800-550 BC). Tijdschrift voor Mediterrane Archeologie, 63, 49.

ÉRARD-CERCEAU, I., FOTOU, V., PSYCHOYOS, O., TREUIL, R., 1993. Prospection archéologique à Naxos. In: R. Dalongeville, and G. Rougemont, eds. Recherches dans les Cyclades. Lyon - Paris: Collection de la Maison de l'Orient Méditerranéen, 23, pp. 59-96.

EVELPIDOU, N., PAVLOPOULOS, K., VASSILOPOULOS, A., TRIANTAPHYLLOU, M., VOUVALIDIS, K., SYRIDES, G., 2012. Holocene palaeogeographical reconstruction of the western part of Naxos island (Greece). Quaternary International, 266, 81-93.

GALlAY, A., et al., 2012. Potières du Sahel a la découverte des traditions céramiques de la Boucle du Niger (Mali). Gollion: Infolio.

GAUSS, W., KLEBINDER-GAUSS, G., VON RÜDEN, C., eds., 2015. The Transmission of Technical Knowledge in the Production of Ancient Mediterranean Pottery, Proceedings of the International Conference at the Austrian Archaeological Institute at Athens, 23 $3^{\text {rd }}-25^{\text {th }}$ November 2012. Wien: Österreichisches Archäologisches Institut.

GELBERT, A., 2003. Traditions céramiques et emprunts techniques dans la vallée du fleuve Sénégal. Ceramic traditions and technical borrowings in the Senegal River Valley. Paris: Éditions de la Maison des sciences de l'homme.

GOROGIANNI, E., ABELL, N., HILDITCH, J., 2016. Reconsidering Technological Transmission. The Introduction of the Potter's Wheel at Ayia Irini, Kea, Greece. American Journal of Archaeology, 120(1), 1-41.

GOSSELAIN, O.P., 2000. Materialising Identities. An African Perspective. Journal of Archaeological Method and Theory, 7, 187-217.

GOSSELAIN, O.P., 2016. To Hell with Ethnoarchaeology. Archaeological Dialogues, 23(2), 215-228.

GRIMANIS, A.P., KATSANOS, A.A., KILIKOGLOU, V., KOUROU, N., MANIATIS, Y., PANAK-LERIDOU, D., VASSILAKI-GRIMANI, M., 1989. An Interdisciplinary Approach of Geometric Pottery from Naxos: Provenance and Technological Studies. In: Y. Maniatis, ed. Archaeometry: Proceedings of the $25^{\text {th }}$ International Symposium on Archaeometry Held in Athens from $19^{\text {th }}$ to $23^{\text {rd }}$ May 1986. Amsterdam - New York: Elsevier, pp. 169-175.

GROS, J.S., 2007. La ceramique commune en Grece centrale au debut de l'age du fer (ca. 1100-675 avant J.-C.): typologies, production, circulation, consommation. Unpublished thesis $(\mathrm{PhD})$, University of Thessaly.

HAMILAKIS, Y., 2016. Decolonial Archaeologies: from Ethnoarchaeology to Archaeological Ethnography. World Archaeology, 48(5), 678-682.

HORDEN, P., and PURCELL, N., 2000. The Corrupting Sea: A Study of Mediterranean History. Oxford: Wiley-Blackwell.

JEFFRA, C.D., 2011. The Archaeological Study of Innovation. An Experimental Approach to the Pottery Wheel in Bronze Age Crete and Cyprus. Unpublished thesis (PhD), University of Exeter.

JEFFRA, C., 2013. A Re-examination of Early Wheel Potting in Crete. Annual of the British School at Athens, 108, 31-49.

JONES, R.E., 1986. Greek and Cypriot Pottery. A Review of Scientific Studies. Athens: British School at Athens.

KIRIATZI, E., and KNAPPETT, C., eds. 2016. Human Mobility and Technological Transfer in the Prehistoric Mediterranean. Cambridge: Cambridge University Press.

KNAPP, A.B., and VAN DOMMELEN, P., eds., 2014. The Cambridge Prehistory of the Bronze and Iron Age Mediterranean. Cambridge: Cambridge University Press.

LAVE, J., and WENGER, E., 1991. Situated Learning. Legitimate Peripheral Participation. Cambridge: Cambridge University Press.

LEROI-GOURHAN, A., 1993. Gesture and Speech. Cambridge: MIT Press.

LIS, B., 2009. Handmade and Burnished Pottery in the Eastern Mediterranean at the End of the Bronze Age: Towards an Explanation 
of its Diversity and Geographical Distribution. In: C. Bachhuber, and R. Gareth Roberts, eds. Forces of Transformation. The End of the Bronze Age in the Mediterranean. Proceedings of an International Symposium held at St. John's College, University of Oxford, 25 th $-26^{\text {th }}$ March 2006. Oxford: Oxbow Books, pp. 152-163.

LIS, B., KIRIATZI, E., BATZIOU, A., RÜCKL, Š., 2020. Dealing with the Crisis: Mobility of Aeginetan-tradition Potters around 1200 BC. Annual of the British School at Athens, 115, 1-59.

LONDON, G., 2000. Women Potters of Cyprus. DVD: 26 minutes. Nicosia: Tetraktys.

LONDON, G., 2020. Wine Jars and Jar Makers of Cyprus: The Ethnoarchaeology of Pitharia. SIMA: Astrom Editions.

MCLOUGHLIN, B., 2011. The Pithos Makers at Zagora: Ceramic Technology and Function in an Agricultural Settlement Context. In: A. Mazarakis Ainian, ed. The "Dark Ages" Revisited. Acts of an International Symposium in Memory of William D. E. Coulson, University of Thessaly, Volos, 14-17 June 2007. Volos: Volos University Press, pp. 913-928.

MCLOUGHLIN, B., and PASPALAS, S.A., forthcoming. Ninth- and early eighth-century Zagora, Andros: Indications of Central Aegean Networks and Engagements. In: D. Athanasoulis, ed. Perì tón Kikládon níson. To Archaiologiko Érgo stis Kikládes. Diethnés Sinédrio, Athína, Vizantinó kai Khristianikó Mousio, 22-26 Noemvríou 2017.

NORWICH, J.J., 2006. The Middle Sea: A History of the Mediterranean. New York: Knopf Doubleday Publishing Group.

PAPADOPOULOU-ZAPHIROPOULOU, P., 1965. Arkhaiótites kai mnimía Kikládon. Náxos. Tsikalarió. ArchDelt, 20, 515-522.

PSAROPOUlOU, B., 2005. I Khristiki Keramiki tou Khthes sti Náxo. Rethymno: Kentro Meletis Neoteris Keramikis.
RODDICK, A., and STAHL, A., 2016. Introduction: Knowledge in Motion. In: A. Roddick, and A. Stahl, eds. Knowledge in Motion: Constellations of Learning Across Time and Place. Tuscon: University of Arizona Press. ROUX, V., and COURTY, M.-A., 2019. Ceramics and Society. A Technological Approach to Archaeological Assemblages. Springer: Switzerland.

RÜCKL, Š., and JACOBS, L., 2016. "With a Little Help from My Wheel": Wheel-Coiled Pottery in Protogeometric Greece. Hesperia, 85, 297-321.

SIMANTONI-BOURNIA, E., 1990. Anaskaphés Náxou. I anágliphi pithi. Athens: Vivliothiki tis en Athinais Archaiologikis Etairías.

SIMANTONI-BOURNIA, E., 2004. La céramique grecque à reliefs, Ateliers insulaires du VIII e au VI e siècle av. J.-C. Hautes études du monde gréco-romain 3. Geneva: Librairie Droz.

STRACK, S., 2007. Regional Dynamics and Social Change in the Late Bronze and Early Iron Age: A Study of Handmade Pottery from Southern and Central Greece. Unpublished thesis (PhD), University of Edinburgh.

WENGER, E., 1998. Communities of Practice. Learning, Meaning and Identity. Cambridge: Cambridge University Press.

ZAPHIROPOULOU, P., 1983. La necropolis geometrica di Tsikalario a Naxos. Magna Grecia, 18(5-6), 1-4.

ZAPHIROPOULOU, P., 2001a. Káfsis stis geometrikés Kikládes. I periptósis tis Náxou kai tis Párou. In: N.Ch. Stampolidis, ed. Káfsis stin Epokhi tou Khalkoú kai tin Próimi Epokhi tou Sidirou. Praktiká tou Simposiou. Rhodos, $29^{\text {th }}$ April-2 $2^{\text {nd }}$ May 1999. Athens: Idiotiki, pp. $285-$ 299.

ZAPHIROPOULOU, P., 2001b. Kikládes - I geometrikí Náxos (10os - 8os ai. p. Kh.). Naxiaká, 2(40), 6-15.

ZAPHIROPOULOU, P., 2008-2009. The Tumulus Necropolis at Tsikalario on Naxos. AIONArch, 15-16, 49-55. 
